\title{
LAS RELACIONES ENTRE EL ESTADO Y LAS CONFESIONES RELIGIOSAS
}

\author{
Jerónimo Borrero Arias \\ Universidad de Sevilla
}

\begin{abstract}
Resumen: Se analiza de modo general el contenido de los Acuerdos suscritos entre el Estado español y diferentes Confesiones religiosas presentes en nuestro país, como la Iglesia Católica y las minorías evangélica, judía e islámica. La firma de estos Acuerdos con las mencionadas minorías constituye una auténtica novedad en el ámbito propio de las fuentes del Derecho Eclesiástico español.

Palabras clave: Cooperación, Confesiones religiosas, Acuerdos Iglesia-Estado, evangélico, judío, islámico.

Abstract: It is analyzed in a general way the content of the Agreements between the Spanish State and different religious entities in our country like the Catholic Church and some Evangelical, Jewish and Islamic entities. The signature of these Agreements with the representatives of the above mentioned minorities represents an authentic novelty in the field of the Spanish Ecclesiastical Law.

Keywords: Cooperation, religious confession, religious entities, Church-State agreements, Evangelical, Jewish, Islamic.
\end{abstract}

\section{CONSIDERACIONES GENERALES}

El presente trabajo pretende ofrecer al lector una visión panorámica y global del contenido de los Acuerdos suscritos entre el Estado español y diferentes Confesiones religiosas presentes en nuestro país, concretamente la Iglesia $\mathrm{Ca}-$ tólica y las minorías evangélica, judía e islámica. No se trata en modo alguno de

1 Este artículo reproduce, actualizada y ampliada, la conferencia dictada el día 6 de noviembre de 2007 en el Aula de Grados de la Facultad de Filología de la Universidad de Sevilla, con ocasión de un Seminario sobre «La aplicación en España de los Códigos de familia musulmanes». Quiero expresar mi agradecimiento por haber sido invitado a participar en este evento. Agradecimiento muy particular al Área de Estudios Árabes e Islámicos, tan bien representada, entre otros excelentes profesores, por los Doctores Pedro Cano, responsable del Grupo de Investigación HUM 135 «El saber en al-Andalus», y Juan Manuel Uruburu, que tanto empeño pusieron para que estas jornadas llegaran a feliz término. Este Grupo de Investigación, desde el año 1994, desarrolla una encomiable labor en el Área de Estudios Árabes e Islámicos de la Facultad de Filología de la Universidad de Sevilla. 
un estudio exhaustivo y pormenorizado, entre otras razones, por la propia extensión de este artículo. Asimismo, se ha renunciado a realizar cualquier tipo de valoraciones sobre una materia que hoy en día se antoja polémica. Finalmente, por razones de espacio, se ha incluido una bibliografía no excesivamente amplia, aunque suficiente para colmar las pretensiones de este trabajo, pues a nadie escapa que resulta imposible dar cuenta aquí de la vasta producción científica sobre cuestiones tan vivas y actuales.

El tema de las relaciones Estado-Confesiones religiosas hay que encuadrarlo dentro del marco de las relaciones comunidad política-comunidad religiosa ${ }^{2}$ y pertenece al ámbito del Derecho Eclesiástico del Estado, que, en apretada síntesis, es la rama del Derecho estatal que regula el fenómeno social religioso en cuanto tiene una incidencia o repercusión en el ámbito civil. En realidad, hoy, el término Derecho Eclesiástico no resulta muy afortunado en la inteligencia de que este sector del ordenamiento jurídico del Estado no sólo se ocupa de las Confesiones cristianas sino también de las no cristianas (judía, islámica, etc). Acaso, sería más acertado y real denominarlo Derecho sobre las religiones o sobre las confesiones religiosas, o, incluso, sobre cultos.

En este sentido, los acuerdos entre España y las confesiones religiosas forman parte de las fuentes del Derecho Eclesiástico español. Son fuentes bilaterales o pacticias. También las hay unilaterales, como la Constitución de 1978 y Ley Orgánica de Libertad Religiosa (en adelante, LOLR), de 5-7-1980³. Estas últimas fuentes emanan exclusivamente del Estado. Por lo demás, los acuerdos con las confesiones religiosas - católica o no-constituyen la fuente más característica del Derecho Eclesiástico ${ }^{4}$.

2 La doctrina suele resumir los actuales sistemas de relaciones entre los Estados y las Confesiones religiosas en el sistema de confesionalidad, el de separación con cooperación, el de separación sin cooperación, y el laicista. En todos ellos se dan subdivisiones y matices (vid., por todos, A. de la Hera, «Las relaciones Estado-Confesiones en la Constitución española de 1978 y en la Ley de Libertad Religiosa de 1980», A Religião no Estado Democrático, Lisboa 2007, pp. 67-80).

3 Vid., por ejemplo, A. C. Álvarez Cortina-M. Rodríguez Blanco (coords.), La libertad religiosa en España: XXV años de vigencia de la Ley Orgánica 7/1980, de 5 de julio (comentarios a su articulado), Edit. Comares, Granada 2006; VV.AA., La nueva realidad religiosa española: 25 años de la Ley Orgánica de Libertad Religiosa, Ministerio de Justicia, Madrid 2006; R. Navarro-Valls-J. Mantecón Sancho-J. Martínez-Torrón (coords.), La libertad religiosa y su regulación legal. La Ley Orgánica de Libertad Religiosa, Iustel, Madrid 2009; J. M. Contreras Mazarío, «La Ley Orgánica de Libertad Religiosa y su reforma», Laicidad y libertades: escritos jurídicos, 9-1 (2009), 117-156; D. Llamazares Fernández, «Revisión de la Ley Orgánica de Libertad Religiosa», Laicidad y libertades: escritos jurídicos, 9-1 (2009), 191-250; J. Mantecón Sancho, «En torno a la anunciada reforma de la Ley Orgánica de Libertad Religiosa», Anuario de Derecho Eclesiástico del Estado (en adelante, ADEE), XXVI (2010), 333-348; S. Cañamares, «Ley Orgánica de Libertad Religiosa: oportunidad y fundamento de una reforma», Ius Canonicum (en lo sucesivo, IC), 50 (2010), 477-515.

${ }^{4}$ Entre la copiosa bibliografía sobre este tema, pueden consultarse las siguientes publicaciones: Iglesia y Comunidad política, Salamanca 1974; A. de la Hera, «Evolución de las doctrinas sobre las relaciones entre la Iglesia y el poder temporal», VV. AA., Derecho Canónico, Pamplona 1975, pp. 611-652; VV.AA., El hecho religioso en la nueva Constitución española, Salamanca 1979; 
Asimismo, conviene recordar que existe un importante número de normas que constituyen un auténtico Derecho Eclesiástico Internacional. Precisamente el art. 10.2 de nuestra Carta Magna establece que "Las normas relativas a los derechos fundamentales y a las libertades que la Constitución reconoce, se interpretarán de conformidad con la Declaración Universal de los Derechos $\mathrm{Hu}-$ manos y los tratados y acuerdos internacionales sobre las mismas materias, ratificados por España”. A este respecto, cabe mencionar la Declaración Universal de Derechos Humanos de la ONU, de 10-12-1948, donde se recuerda que ninguna persona debe ser discriminada por motivos religiosos (art. 2) y se recoge el derecho a la libertad de pensamiento, de conciencia y de religión (art. 18). Esta Declaración, pese a su carácter universal, no es más que una simple declaración no vinculante jurídicamente y su aceptación es más teórica que real, en la medida en que una cosa es la proclamación solemne de unos derechos y otra muy diferente su tutela sincera y efectiva. Precisamente, para una mayor eficacia en la protección de aquéllos, los Estados miembros del Consejo de Europa firmaron en Roma el «Convenio para la Protección de los Derechos Humanos y de las Libertades Fundamentales» (4-11-1950). Este Convenio, ratificado por España el 26-9-1979, reproduce, en parecidos términos, en su art. 9.1, el contenido del mencionado art. 18 de la Declaración de la ONU. Sin embargo, en el párrafo 2 se introduce una referencia explícita a los límites del derecho de libertad religiosa: "La libertad de manifestar su religión o sus convicciones no puede ser objeto de más restricciones que las que, previstas por la ley, constituyen medidas necesarias, en una sociedad democrática, para la seguridad pública, la protección del orden, de la salud o de la moral públicas, o la protección de los derechos o las libertades de los demás" 5 . En la actualidad, para velar por el cumplimiento de este Convenio existe un Tribunal permanente que conserva la denominación de Tribunal Europeo de Derechos Humanos. En la misma línea,

J. J. Giménez y Martínez de Carvajal-C. Corral, Iglesia y Estado en España. Régimen jurídico de sus relaciones, Madrid 1980; C. Corral-L. Echeverría, Los acuerdos entre la Iglesia y España, Madrid 1980; J. Fornés, El nuevo sistema concordatario español (Los Acuerdos de 1976 y 1979), Pamplona 1980; A. Motilla, Los acuerdos entre el Estado y las confesiones religiosas en el Derecho español, Barcelona 1985; VV.AA., Las relaciones entre la Iglesia y el Estado. Estudios en memoria del profesor Pedro Lombardía, Universidad Complutense de Madrid-Universidad de Navarra, 1989; J. Otaduy (coord.), Tratado de Derecho Eclesiástico, Pamplona 1994; J. M. Vázquez García-Peñuela-

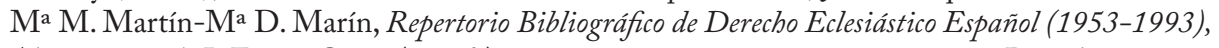
Almería 1995; J. Ferrer Ortiz (coord.), Derecho Eclesiástico del Estado Español, Pamplona 1996; A. Bernárdez, Lecciones de Derecho Eclesiástico Español («Ad usum privatum»), Facultad de Derecho, Sevilla 1999; J. Ma. González del Valle, Derecho Eclesiástico Español, Navarra 2005; J. Bogarín Díaz, «Factor religioso y relaciones entre ordenamientos jurídicos», ADEE, XXIII (2007), 51142; C. Corral, Confesiones religiosas y Estado español. Régimen jurídico, Madrid 2007; A. Barrero Ortega, Modelos de relación entre el Estado y la Iglesia en la historia constitucional española, Cádiz 2007; Ma. R. León Benítez-Ma. M. Leal Adorna, Derecho y factor religioso ("Ad usum privatum"), Delta Publicaciones Universitarias, Madrid 2009.

5 Vid., por ejemplo, P. Lombardía-J. Fornés, «E1 Derecho Eclesiástico», J. Ferrer Ortiz (coord.), Derecho Eclesiástico ..., cit., p. 57; J. M. González del Valle, Derecho Eclesiástico..., cit., pp. 68-71. 
se muestran otros acuerdos, que convierten el contenido de la Declaración Universal en un texto vinculante para los Estados, como el «Pacto Internacional de Derechos Económicos, Sociales y Culturales» y el «Pacto Internacional de Derechos Civiles y Políticos» ${ }^{6}$. Sendos tratados, de 19-12-1966, fueron ratificados por España el 13-4-1977. Para un mejor cumplimiento de estos pactos existen los Comités de Derechos Humanos y de Derechos Económicos, Sociales y Culturales.

También existe un incipiente Derecho de la Unión Europea con ciertas novedades de interés. De las mismas características de la legislación participa la jurisprudencia del Tribunal de Justicia de las Comunidades Europeas sobre materias propias del Derecho Eclesiástico. Por otra parte, la «Carta de los Derechos Fundamentales de la Unión Europea», de 18-12-2000, es una clara consecuencia de la progresiva preocupación de ésta por la protección y tutela de los derechos fundamentales ${ }^{7}$.

A la hora de exponer en términos generales las relaciones de cooperación entre el Estado y las confesiones religiosas es obligado recurrir al art. 16.3 de nuestra Constitución donde se dice expresamente que "Los poderes públicos tendrán en cuenta las creencias religiosas de la sociedad española y mantendrán las consiguientes relaciones de cooperación con la Iglesia Católica y las demás confesiones". Observa la doctrina que es la concepción positiva de lo religioso, como valor individual y social, la que lleva al Estado a colaborar con las Iglesias y Confesiones en el común servicio a los hombres. En el orden público, esta cooperación se plasmará en acuerdos y convenios. Con la Iglesia Católica, al ser sujeto de Derecho Internacional, tendrán el rango de Tratados de Derecho Internacional. Las relaciones con las restantes confesiones religiosas, al carecer de esa personalidad, se plasmarán en convenios de Derecho público interno ${ }^{8}$.

Por Confesiones religiosas hay que entender "aquellas agrupaciones de personas constituidas en torno a un núcleo de principios doctrinales y de orientaciones prácticas referentes al orden trascendente de la vida humana (por tanto referentes a Dios, como ser Superior que se relaciona con los hombres y les señala un destino espiritual) dotadas de una organización más o menos evolucionada”. En concreto, el Derecho positivo español se sirve indistintamente de los términos Comunidades, Iglesias o Confesiones religiosas. Así, en el art. 16 de la Constitución aparecen las expresiones «comunidades» $\mathrm{y}$ "confesiones religiosas» y la LOLR utiliza, además de estas mismas locuciones, el término «Iglesias»". Realmente, la terminología de la que hacen uso los textos legales no es uniforme

${ }^{6}$ En el art.18.2 de este Pacto se dice expresamente que "nadie será objeto de medidas coercitivas que puedan menoscabar su libertad de tener o de adoptar la religión o las creencias de su elección".

7 Vid., por todos, J. M. González del Valle, Derecho Eclesiástico..., cit., pp. 73-76.

8 J. Giménez y Martínez de Carvajal, «Principios informadores...», cit., p. 47.

9 A. Bernárdez, Lecciones ..., cit., p. 105. 
ni clara ${ }^{10}$, de ahí que el concepto de confesión religiosa haya que entenderlo en un sentido amplio. En principio, el vocablo Iglesia designa las diversas organizaciones existentes dentro del Cristianismo, por reconocer a Cristo como fundador, aunque constituyan ramas distintas e independientes y medien entre ellas importantes diferencias teológicas, sacramentales y litúrgicas (católicos, ortodoxos, protestantes). El término Comunidades religiosas viene a aludir a las religiones no cristianas (judaísmo, islamismo, hinduismo, etc.). En cambio, la expresión «Confesión religiosa» se aplica indistintamente a cualquier movimiento, agrupación u organización de esta naturaleza. Finalmente, el término entes o entidades religiosas (eclesiásticas, confesionales) encierra un contenido más concreto, comprendiendo aquellos grupos, organismos o institutos que se establecen con cierta independencia dentro de la agrupación o confesión general y a los que se les confiere una vida propia si bien, en cierta medida, supeditada a las exigencias y directrices de dicha agrupación o confesión ${ }^{11}$.

En términos más concretos, en lo que se refiere al ordenamiento jurídico español, habría que distinguir los siguientes tipos de confesiones: la Iglesia Católica, las confesiones que han suscrito un acuerdo con el Estado, las confesiones inscritas en el Registro de Entidades Religiosas y las confesiones no inscritas. Cabe añadir a este elenco los denominados nuevos movimientos religiosos ${ }^{12}$.

Los acuerdos del Estado con la Santa Sede, suelen plasmarse, por lo común, bien en forma de Concordato o bien en forma de Acuerdos parciales. Por lo que se refiere a España, las relaciones con la Iglesia Católica tienen lugar por vía concordataria. Si bien no hay un Concordato en el sentido que a continuación se explicará, sí existe un régimen concordado articulado a través de Acuerdos específicos ${ }^{13}$.

El Concordato ${ }^{14}$ — cuyo significado no es otro que "pacto entrañable" o "unión de corazones" ("cor-cordis") — es un convenio o acuerdo celebrado entre la Iglesia y el Estado a fin de regular, desde el punto de vista jurídico-positivo, una serie de problemas que atañen a sus respectivas esferas. Se trata, en definitiva, de las denominadas materias mixtas o materias que atañen a uno y otro ámbito (nombramiento de obispos, enseñanza, matrimonio...). Este tipo de pacto viene a ser un texto amplio y global, es decir un solo documento en

10 Vid., entre la abundante bibliografía, D. García Hervás, «Las confesiones religiosas y sus entes», D. García Hervás (coord.), Manual de Derecho Eclesiástico del Estado, Madrid 1997, pp.157-158.

11 A. Bernárdez, Lecciones ..., cit., pp. 105-106. Vid. sobre este tema A. Motilla, Los Acuerdos..., cit., pp. 303-312.

12 Por ejemplo, I. C. Ibán, «Las confesiones religiosas», en I. C. Ibán-L. Prieto Sanchís-A. Motilla, Curso de Derecho Eclesiástico, Madrid 1991, pp. 223-278.

13 A. Bernárdez, Lecciones..., cit., p. 49.

14 Para una valoración global de los concordatos pueden consultarse, entre otros innumerables trabajos, VV.AA, La institución concordataria en la actualidad, Salamanca 1971; J. Giménez y Martínez de Carvajal, «Los concordatos en la actualidad», Derecho Canónico, cit., pp. 715-768; J. M. García-Peñuela (ed.), Los concordatos: pasado y futuro, Almería 2003. 
el que se pretende establecer un sistema complejo de relaciones Iglesia-Estado mediante la regulación de todas las materias que previsiblemente puedan afectar a ambas competencias. A título de ejemplo, cabe invocar, en la Edad Moderna y Contemporánea, los Concordatos españoles de 1753, suscrito entre Benedicto XIV y Fernando VI; de 1851, entre Pío IX e Isabel II, y de 1953, entre Pío XII y Franco, que constituyó un auténtico espaldarazo para el Régimen. Por otra parte, en la actualidad hay un buen número de países con Concordato. Sirvan de ejemplo, entre otros, Alemania (1933), Italia (1984), Polonia (1993) o Portugal (2004), en Europa; o la República Dominicana (1954) y Colombia (1973), en ultramar ${ }^{15}$.

Pero también pueden plasmarse estos tratados en forma de acuerdos parciales o, con más propiedad, acuerdos específicos. A la hora de la sustitución del antiguo Concordato español de 1953, se discutió si era preferible un texto único, es decir, otro concordato, o varios textos, y se optó por este último sistema dadas las ventajas que ofrecía. Entre ellas, es posible la denuncia de uno o varios acuerdos con independencia de los restantes. Sin embargo, al gozar de cierta unidad moral, en buena lógica, en el supuesto de violación de uno de ellos, la otra parte se considerará desvinculada de la obligación de observar lo estipulado en los demás ${ }^{16}$. En definitiva, huelga decir que los Acuerdos vienen a ser lo mismo que un concordato, pues la unidad de un concordato, al igual que la de un código, no deriva de la unidad de documento sino de tema y normativa. Con particular claridad, algún autor ha venido a expresar que "lo único que les falta para ser un concordato es el nombre" 17 .

Conviene hacer una precisión en relación con los sujetos firmantes del concordato o del acuerdo: por parte del Estado, el sujeto no es el Gobierno sino el Estado o, mejor, la Comunidad política sobre la cual recaen sus efectos. En este sentido, el derogado Concordato italiano de 1929 continuó vigente a pesar de la sucesión de los regímenes políticos: con monarquía saboyana y sistema fascista, y con república constitucional de 1947, que mantiene la mutua independencia Iglesia-Estado y los Pactos Lateranenses, modificables por acuerdo de las dos partes sin necesidad de un procedimiento de revisión constitucional. Análogamente, el «ReichsKonkordat» (1933) continúa vigente en la República

15 Vid. sobre el tema C. Corral-S. Petschen, Concordatos vigentes, 3 tomos, Madrid 1981 y 1996; los acuerdos más recientes pueden consultarse, por ejemplo, en Idem, Tratados Internacionales (1996-2003) de la Santa Sede con los Estados. Concordatos vigentes. Tomo IV, Madrid 2004; J. T. Martín de Agar, Raccolta di concordati 1950-99, Libreria Editrice Vaticana, 2000; Idem, I Concordati dal 2000 al 2009, Libreria Editrice Vaticana, 2010.

16 P. Lombardía-J. Fornés, «Fuentes del Derecho Eclesiástico Español», J. Ferrer Ortiz (coord.): Derecho Eclesiástico..., cit., p. 96.

17 I.C. Ibán-L. Prieto-A. Motilla, Manual de Derecho Eclesiástico, Madrid 2004, p. 117. Un resumen de las ventajas que ofrece la fórmula de los Acuerdos parciales o específicos, puede verse en J. Giménez y Martínez de Carvajal, «Principios informadores...», cit., p. 48. 
Federal Alemana ${ }^{18}$. En relación con la Iglesia actúa la Santa Sede, la cual goza de personalidad internacional. Esta personalidad se le reconoce en cuanto personificación de la Iglesia Católica (institución de ámbito universal dotada de un régimen orgánico unitario) y no como entidad que tiene su base en un Estado reconocido en el orden internacional, cual es el Estado de la Ciudad del Vaticano. En términos más concretos, la Santa Sede es quien representa a la Iglesia Católica en dicho ámbito ${ }^{19}$. Así se comprende que cuando Italia conquistó los Estados Pontificios y el Papa se vio privado de un territorio del que era soberano en el orden temporal, la independencia de la Santa Sede continuó siendo reconocida por la praxis internacional ${ }^{20}$.

Por otra parte, resulta, cuanto menos curioso, que, con cierta frecuencia, se cae en el grave error de afirmar gratuitamente que el Estado español pretende cambiar el Concordato con el Vaticano. Quienes esto afirman incurren en un doble dislate, pues no hay tal concordato, sino un régimen concordado de acuerdos específicos, y, lo que es aún peor, confunden el Estado Vaticano con la Santa Sede. $Y$ es ésta precisamente quien posee la personalidad internacional.

Dejando a un lado otras cuestiones en las que no nos es dado entrar por exceder del cometido específico de este trabajo, en la actualidad, para la elaboración del texto - concordato o acuerdo - se nombran en primer lugar los ministros plenipotenciarios, los cuales negocian y elaboran el texto. Por parte de la Iglesia, es la Santa Sede quien inicia las negociaciones nombrando sus ministros plenipotenciarios. Y el Romano Pontífice es quien lo ratifica. Por parte del Estado, inicia las negociaciones el gobierno de la nación; negocian los plenipotenciarios; las cámaras legislativas lo aprueban y lo ratifica el Jefe del Estado.

\section{LOS VIGENTES ACUERDOS ENTRE ESPAÑA Y LA SANTA SEDE 21}

Es incuestionable que en España, bien entrada la segunda mitad de la centuria pasada acaecieron unos profundos cambios sociológicos, políticos ${ }^{22}$ y religiosos. Esta transformación tuvo, obviamente, especial repercusión en las relaciones entre la Iglesia y el Estado. Éste renunció a la intervención en la vida de la Iglesia; intervención que, por lo demás, había ejercido durante siglos. La Iglesia, por su parte, se situó en una posición de igualdad esencial con las demás confesio-

18 A. Bernárdez, Lecciones..., cit., p. 56.

19 J. M. González del Valle, Derecho Eclesiástico..., cit., p. 91.

20 P. Lombardía-J. Fornés, «Fuentes del Derecho Eclesiástico Español», J. Ferrer Ortiz (coord.), Derecho Eclesiástico..., cit., pp. 88-89.

21 Vid., por ejemplo, Caparrós, $M^{a}$ C.-Martín, $M^{a}$ M.-Salido, $M^{a}$ (coords.), $X X X$ años de los Acuerdos entre España y la Santa Sede, Edit. Comares, Granada 2010; A. C. Álvarez Cortina, «Los acuerdos de 1979 a los treinta años de su ratificación (referencias para un repaso doctrinal)», ADEE, XXVI (2010), 963-969.

22 Un análisis político de los Acuerdos del Estado español con la Santa Sede en la época en que fueron firmados, puede verse, por ejemplo, en M. García, «Valoración política», C. Corral-L. Echeverría, Los acuerdos..., cit., pp. 749-773. 
nes y renunció a la situación de privilegio de la que, también desde época ancestral, había gozado en España ${ }^{23}$. Recordemos en este sentido como el derogado Concordato de 1953 en su art. I establecía que "La Religión Católica, Apostólica, Romana sigue siendo la única de la Nación española...”. En consecuencia, y sólo a título de ejemplo, si los católicos españoles pretendían contraer matrimonio civil debían realizar una declaración de acatolicidad...; los impedimentos matrimoniales canónicos también lo eran civiles (orden sagrado, voto, impotencia...). En definitiva, España había optado por la afirmación más solemne de la confesionalidad del Estado. No sólo se trataba de un reconocimiento sociológico o, incluso, jurídico en sentido estricto, sino también teológico ${ }^{24}$.

Pues bien, el antiguo principio básico de la confesionalidad católica del Estado español va a dejar paso al de neutralidad religiosa o no confesionalidad (art. 16 de la Constitución). Aunque no se puede ignorar la realidad sociológica y cuantitativa de la Iglesia Católica en España, la libertad religiosa hace acto de presencia y viene a sustituir a la antigua protección prestada a aquella confesión religiosa, que gozaba de una situación privilegiada frente a las restantes confesiones. A todas ellas se aplicarán esencialmente los mismos principios fundamentales que consagra la Constitución. Asimismo, el Estado reconoce el valor social de las religiones y, en particular, de la Iglesia Católica que, por lo demás, constituye un elemento esencial e insustituible en la historia y cultura españolas, así como un factor de paz, justicia y convivencia ${ }^{25}$. Precisamente, el Concilio Vaticano II ha marcado las dos líneas básicas de las relaciones Iglesia-Estado: por una parte, la distinción, por razón de su competencia y misión, entre la Iglesia y la Comunidad política que son independientes y autónomas, y, por otro lado, la cooperación que debe existir entre ellas. En síntesis: la mutua independencia de ambas sociedades más una sana colaboración; "colaboración en la independencia”, como acertadamente puntualiza algún autor ${ }^{26}$.

Antes de la Constitución de 1978 las relaciones Iglesia-Estado se cobijaban en el ámbito del Concordato de 27 de agosto de 1953 y de una serie de convenios provisionales firmados con anterioridad al mismo, así como de un posterior acuerdo al que se hará referencia más adelante. Un cúmulo de acontecimientos determinaron la crisis del Concordato ${ }^{27}$. Podría invocarse, por ejemplo, la cuestión de la aplicación de los privilegios del fuero y de presentación. Precisamente, en 1968 Pablo VI escribirá al Jefe del Estado español rogando su re-

23 J. Giménez y Martínez de Carvajal, «Principios informadores...», cit., pp. 49-51.

24 L. de Echeverría, «La nueva Constitución ante el hecho religioso», El hecho religioso..., cit., p. 47.

25 Ibidem.

26 J. Giménez y Martínez de Carvajal, «Principios doctrinales de las relaciones Iglesia-Estado», Iglesia y Comunidad politica, cit., pp. 129-144.

27 Entre otros, J. M. Díaz Moreno, «Historia del texto», C. Corral-L. Echeverría, Los acuerdos. . ., cit., pp. 79-95. Idem, «El proceso de negociación y conclusión de los Acuerdos entre la Santa Sede y el Estado español de 1979», Aconfesionalidad del Estado, laicidad e identidad cristiana, Subcomisión Episcopal de Universidades. Conferencia Episcopal Española, Madrid 2006, pp. 13-48. 
nuncia a este último privilegio, a lo que Franco respondería proponiendo una revisión global del texto concordatario. Este momento puede considerarse como el de formalización de la crisis. En 1971 se elabora un anteproyecto, conocido como el proyecto Garrigues-Casaroli28; posteriormente tiene lugar la firma de un Acuerdo en 1976 y, tres años más tarde, se suscriben cuatro Acuerdos que vienen a conformar buena parte del régimen concordado español. En realidad, buena parte porque a estos acuerdos de 1976 y 1979 habría que añadir otros dos: 1) el único texto no recogido en las disposiciones derogatorias del Concordato de 1953 y de sus convenios complementarios, es el Convenio de 5 de abril de 1962 sobre el reconocimiento, a efectos civiles, de estudios de ciencias no eclesiásticas realizadas en Universidades de la Iglesia. De ahí que continúe en vigor para las cuatro Universidades que en su día se acogieron a él y que son las siguientes, con sus correspondientes fechas de reconocimiento por el Estado: Navarra (89-1962), Deusto y Pontificia de Salamanca (ambas, 7-9-1963) y Comillas (44-1979). 2) El último Acuerdo entre el Reino de España y la Santa Sede al que hay que hacer referencia es el relativo a asuntos de interés común en Tierra Santa (21-12-1994) ${ }^{29}$. En él se intenta poner solución a problemas históricos acerca de determinadas propiedades en Tierra Santa y en otros lugares, como es el caso de Estambul, cuya titularidad no es clara, y en cuya custodia están implicadas, de alguna manera, la Iglesia Católica y España ${ }^{30}$. Este acuerdo tiene obviamente naturaleza de tratado internacional pero difícilmente podría incluirse en el Derecho concordatario propiamente dicho.

Antes de analizar, de manera sucinta, el contenido de los acuerdos de 1976 y 1979, conviene dar noticia de otro tipo de acuerdos «menores» como, por ejemplo, los suscritos con la Conferencia Episcopal o las Autonomías ${ }^{31}$. Concretamente, entre las Comunidades Autónomas y las autoridades eclesiásticas (obispos) correspondientes a su territorio se han firmado numerosos convenios sobre asistencia religiosa católica en hospitales, sobre conservación del patrimonio histórico, artístico y monumental y, en general, sobre el fenómeno religioso $^{32}$. En este sentido, el hecho de que se preste asistencia religiosa católica en hospitales públicos es algo que se establece en un acuerdo Santa Sede-Es-

28 A. Bernárdez: Lecciones ..., cit., p. 71.

29 Vid. al respecto el valioso y documentado artículo de R. Palomino, «El Acuerdo entre el Reino de España sobre asuntos de interés común en Tierra Santa. Una perspectiva histórico-jurídica, diez años después", Revista General de Derecho Canónico y Derecho Eclesiástico del Estado (en adelante, $R G D C D E E), 2$ (2003), iustel.com, última visita 25-9-2009.

30 I. C. Ibán, Manual..., cit., p. 118.

31 Se ha referido a este tema, por ejemplo, A. Martínez Blanco, Las relaciones de las comunidades Autónomas con la Iglesia, Murcia 1987. Asimismo, cabe mencionar una interesante publicación que ofrece una visión global del fenómeno religioso en las diferentes Comunidades Autónomas: R. García García (dir.), La libertad religiosa en las Comunidades Autónomas. Veinticinco años de su regulación jurídica, Barcelona 2008.

32 En cada número del $A D E E$ se da cumplida respuesta de esta temática. Puede verse también, a modo de ejemplo, M. Rodríguez Blanco, Los convenios entre las Administraciones Públicas y 
tado (máximo nivel), pero su regulación requiere un desarrollo a un nivel inferior (Jerarquía eclesiástica española-Administración central) y su aplicación (implementación) pasa por un desarrollo pactado a un nivel todavía más inferior (Jerarquía diocesana-Administración autonómica) ${ }^{33}$. A este respecto, sirva de ejemplo el Convenio de cesión institucional del Palacio de San Telmo a la Junta de Andalucía (1989)34. Estos convenios no tienen rango de tratado internacional sino sólo de Derecho público interno.

\section{A. El acuerdo de 1976}

En teoría, este Acuerdo de 28 de julio de 1976 trata sólo de dos puntos básicos: privilegios del fuero y de presentación. Sin embargo, en la práctica es mucho más amplio por ir precedido de un breve pero sustancioso «preámbulo» ${ }^{35}$, con el compromiso de entablar negociaciones para sustituir al Concordato de 1953. En esta introducción se recogen los principios generales en los que se inspiraría la reforma: la necesidad de una nueva reglamentación de las relaciones entre la Iglesia y el Estado; el compromiso de llevarla a cabo mediante Acuerdos que sustituyan gradualmente las correspondientes disposiciones concordatarias; considerar como cuestiones prioritarias la libertad de la Iglesia en el nombramiento de los Obispos y la igualdad de los todos los ciudadanos frente a la administración de justicia ${ }^{36}$. La reforma vendría apoyada por tres hechos fundamentales: el profundo proceso de transformación experimentado por la sociedad española; la doctrina del Concilio Vaticano II sobre las relaciones entre la comunidad política y la Iglesia ${ }^{37}$, tanto la mutua independencia de ambas partes, en su propio campo, cuanto una sana colaboración entre ellas; y el derecho a la libertad religiosa, reconocido en el ordenamiento jurídico español ${ }^{38}$. Como se ha indicado líneas atrás, este Acuerdo de 1976 consta de dos artículos derogatorios del privilegio de presentación de obispos por parte del Estado y del privilegio del fuero por parte de la Iglesia.

las Confesiones religiosas, Pamplona 2003; J. Bogarín Díaz-A. Ma . López Medina, «Los Convenios de marzo de 1997 entre la Universidad y la Diócesis onubenses», ADEE, XIV (1998), 621-632.

33 I. C. Ibán, Manual..., cit., pp. 120-121.

34 De obligada lectura sobre este tema es la impecable obra de A. Ribelot, Vida azarosa del Palacio de San Telmo. Su historia y administración eclesiástica, Sevilla 2001.

35 Así fue calificado por el ilustre canonista y eclesiasticista A. Bernárdez Cantón (Lecciones..., cit., p. 64).

36 Cfr. J. Giménez y Martínez de Carvajal, «Principios informadores...», cit., p. 27

37 Estas transformaciones, escribía L. de Echeverría en 1977, eran fáciles de captar: "un crecimiento vertiginoso de la población urbana; una profunda crisis de fe en extensas zonas de la población, y muy especialmente en la juventud; una mayor permisibilidad en las costumbres, una crisis de autoridad, con abierto rechazo a la obediencia como tal; una antipatía hacia toda institución, particularmente si esta es religiosa...” «La recíproca renuncia de la Iglesia y del Estado a los privilegios del Fuero y de Presentación de Obispos», Estudios Eclesiásticos, 52 (1977), 198-199].

38 J. Giménez y Martínez de Carvajal, «Principios informadores...», cit., p. 27. 


\section{Privilegio de presentación}

No resultó fácil conseguir la renuncia por parte del Estado español al privilegio de presentación. Ya el Concilio Vaticano II (Decreto "Christus Dominus" n 20) había prohibido que en el futuro se concediera a las autoridades civiles cualquier tipo de intervención en este tema y, al mismo tiempo, se rogaba «humanísimamente» a los Gobiernos católicos, que tuvieran tales derechos o privilegios, que renunciaran a ellos «espontáneamente» después de consultada la Sede Apostólica. Pero esta intervención no tuvo eco en España (sí en Argentina, en 1966). Por ello, Pablo VI escribe al Jefe del Estado, el 29 de abril de 1968, rogando su renuncia al privilegio de presentación de obispos. Pero Franco no se muestra muy sensible ante la situación y, el 12 de junio del mismo año, contesta en el sentido de que la renuncia a tal "derecho" debe quedar encuadrada en una revisión que afecte a los privilegios de las dos potestades, dentro del espíritu del propio Concilio. En definitiva, a partir de este momento, el problema sólo podría encontrar una solución con la revisión total del Concordato de $1953^{39}$. Con acierto, algún autor ha calificado la respuesta del Jefe del Estado de "tardía y habilísima"

¿Qué dice sobre este tema el A. 1976?: "El nombramiento de Arzobispos y Obispos es de exclusiva competencia de la Santa Sede". Se constata, por tanto, que el cambio es espectacular, pues en el régimen derogado ${ }^{41}$, producida una vacante, el Nuncio — puestos de acuerdo el Estado y la Santa Sede- enviaba a Roma una lista de nombres de personas idóneas, al menos seis. De éstos, el Romano Pontífice elegía tres. Y el Jefe del Estado, en el plazo de treinta días, presentaba oficialmente uno de ellos. Pero en el supuesto de que Su Santidad no estimase aceptables todos o parte de los nombres comprendidos en la lista, formulaba o completaba una terna de candidatos, comunicándola por el mismo conducto, es decir, por medio de la Nunciatura, al Gobierno español. Lo que quiere decir que los nuevos nombres se regían por el denominado sistema de prenotificación. El Gobierno disponía de treinta días para formular a la Santa Sede objeciones de carácter político general. En el caso de que las formulase, se continuaban las negociaciones aun transcurrido dicho plazo. Se ha escrito que este texto era complicado e impreciso, por lo que andando el tiempo surgieron las disensiones, haciéndose más penosa la dificultad de ponerse de acuerdo sobre los candidatos ${ }^{42}$. La cuestión no era baladí.

El Acuerdo vigente, que contrasta abiertamente con el régimen establecido en el Concordato de 1953, puntualiza, además, que «Antes de proceder al nombramiento de Arzobispos y Obispos [...], la Santa Sede notificará el nombre del designado al Gobierno español, por si respecto a él existiesen posibles

39 Ibidem, p. 25.

40 J.M. Díaz Moreno, «Historia del texto», cit., p. 81.

41 En este punto, el Concordato de 1953 remitía al «Acuerdo sobre el modo de ejercicio del privilegio de presentación entre el Gobierno español y la Santa Sede», de 7 de junio de 1941.

42 T. García Barberena, «Nombramiento de obispos», C. Corral-L. Echeverría, Los acuerdos. .., cit., pp.132-133. 
objeciones concretas de índole política general ${ }^{43}$, cuya valoración corresponderá a la prudente consideración de la Santa Sede. Se entenderá que no existen objeciones si el Gobierno no las manifiesta en el término de quince días».

Sólo el Vicario General Castrense continúa nombrándose mediante una terna previa semejante a la del régimen anterior. La terna de nombres está «formada de común acuerdo entre la Nunciatura Apostólica y el Ministerio de Asuntos Exteriores y sometida a la aprobación de la Santa Sede. El Rey presentará, en el término de quince días, uno de ellos para su nombramiento por el Romano Pontífice» ${ }^{44}$.

\section{Privilegio del fuero}

Recuérdese que en el régimen derogado (art. XVI del Concordato de 1953) los Prelados no podían ser emplazados ante un juez laico sin la licencia previa de la Santa Sede. Para los demás clérigos y religiosos había que distinguir entre causas contenciosas y causas criminales. Las primeras sobre bienes o derechos temporales, eran tramitadas ante los Tribunales del Estado previa notificación al Ordinario del lugar; las causas criminales podían ser juzgadas por los Tribunales seculares. Sin embargo, la Autoridad judicial, antes de proceder, debía solicitar el consentimiento del Ordinario. En el supuesto de que éste, por graves motivos, se negara a ello, debía comunicarlo por escrito a la Autoridad competente. Según el Concordato de 1953, las penas de privación de libertad eran cumplidas en casas eclesiásticas o religiosas o en locales distintos de los destinados a los seglares (cárcel "concordataria" de Zamora) ${ }^{45}$.

El Acuerdo de 1976 deroga este régimen y nos brinda la siguiente fórmula: "Si un clérigo o religioso es demandado criminalmente, la competente Autoridad lo notificará a su respectivo Ordinario. Si el demandado fuera Obispo, o persona a él equiparada en el Derecho Canónico, la notificación se hará a la Santa Sede". Se sustituye, pues, la licencia por una "notificación" para las causas criminales de "todos". Entiéndase que para las causas civiles y contenciosas (es decir, para las no criminales o penales) no se exige notificación o licencia alguna. En términos más concretos, en el régimen anterior la autoridad judicial, antes de proceder, en causa criminal, contra un clérigo o religioso, debía solicitar el consentimiento del Ordinario del lugar en que se instruía el proceso. Este consentimiento solía concederse de forma automática en los casos de delitos comunes. Pero, cuando se trataba de un "delito político" era frecuente que el Obispo no diera su consentimiento, en particular si había sido cometido en el ejercicio

43 Sobre esta cuestión puede verse el interesante artículo de M. López Alarcón, «La cláusula política en el Derecho concordatario español», Revista Española de Derecho Canónico (en lo sucesivo, $R E D C$ ), 34 (1978), 25-56.

44 Se ha referido al tema, entre otros, C. Seco Caro, «La provisión del arzobispado castrense en el Derecho Eclesiástico español», Las relaciones entre la Iglesia y el Estado. Estudios en memoria del profesor Pedro Lombardía, cit., pp. 491-510.

45 Por ejemplo, L. de Echeverría, «La recíproca renuncia...», Estudios Eclesiásticos, cit., p. 216. 
del ministerio sacerdotal y especialmente en la predicación. Ello, lógicamente, provocó serias tensiones entre las autoridades eclesiásticas y las civiles ${ }^{46}$.

Entre otras cuestiones, también se refiere el Acuerdo a que «En ningún caso los clérigos y los religiosos podrán ser requeridos por los jueces u otras Autoridades para dar información sobre personas o materias de que hayan tenido conocimiento por razón de su ministerio». Por ejemplo, establece el vigente Código de Derecho Canónico que «El confesor que viola directamente el sigilo sacramental, incurre en excomunión latae sententiae reservada a la Sede Apostólica» (canon 1388, § 1).

\section{B. Acuerdos de 1979}

Mayor protagonismo van a tener los cuatro Acuerdos suscritos hace más de tres décadas, el 3 de enero de 1979, con vigencia a partir del 4 de diciembre del mismo año: sobre asuntos jurídicos; sobre enseñanza y asuntos culturales; sobre asistencia religiosa a las Fuerzas Armadas y servicio militar de clérigos y religiosos y sobre asuntos económicos.

\section{Acuerdo sobre Asuntos Juridicos (VII arts.)}

Tiene un valor primordial por cuanto regula cuestiones básicas y fundamentales, de ahí que haya sido calificado de central o nuclear ${ }^{47}$. Comienza afirmando que el Estado reconoce a la Iglesia Católica el derecho de ejercer su misión apostólica y le garantiza el libre y público ejercicio de las actividades que le son propias, en particular las de culto ${ }^{48}$, jurisdicción y magisterio. A continuación se ocupa, entre otros aspectos, de la organización de la Iglesia en España; de la personalidad jurídica de los entes eclesiásticos; reconoce también la personalidad jurídica civil de la Conferencia Episcopal y de las asociaciones y entidades de vida religiosa. Se hace eco, además, de los días festivos; garantiza la inviolabilidad de los lugares de culto con arreglo a las leyes, no pudiendo ser demolidos si previamente no han sido privados de su carácter sagrado. Por otra parte, el Estado reconoce y garantiza el ejercicio del derecho a la asistencia religiosa de los ciudadanos internados en establecimientos penitenciarios, hospitales, sanatorios, orfanatos y centros similares, tanto privados como públicos. Es preciso

46 J. Giménez y Martínez de Carvajal, «Principios informadores...», cit., p. 25, nota 27. Un estudio amplio sobre el tema puede verse, por ejemplo, en L. de Echeverría, «Renuncia a privilegios», Iglesia y Comunidad politica, cit., pp. 169-208.

47 A. Bernárdez, Lecciones..., cit., p. 73.

48 Dado que por vez primera y a nivel autonómico se afronta la regulación expresa de las condiciones que los centros de culto han de poseer para su apertura, resulta de interés consultar, por ejemplo, J. A. Rodríguez García, «La ley catalana de centros de culto y la laicidad», Laicidad y libertades: escritos jurídicos, 9-1 (2009), 403-441; M. Leal Adorna, «El Decreto 94/2010, de 20 de julio, de desarrollo de la Ley 16/2009, de 22 de julio, de centros de culto de Cataluña», $R G D C$ DEE, 26 (2011), iustel. com, última visita 21-3-2012. 
destacar, finalmente, el tema del reconocimiento de efectos civiles al matrimonio canónico ${ }^{49}$, dejando plena libertad a los contrayentes para elegir la clase de matrimonio que prefieran. Asimismo, los esposos, a tenor de las disposiciones del Derecho Canónico, podrán acudir a los tribunales eclesiásticos y solicitar declaración de nulidad o pedir decisión pontificia sobre matrimonio rato y no consumado. Y a solicitud de cualquiera de las partes, estas resoluciones eclesiásticas tendrán eficacia en el orden civil si se declaran ajustadas al Derecho del Estado en resolución dictada por el tribunal civil competente ${ }^{50}$.

\section{Acuerdo sobre Enseñanza y Asuntos Culturales}

Es el de mayor contenido (XVII arts.) ${ }^{51}$. En este Acuerdo se establece la enseñanza de la religión católica en centros docentes y se reconoce el derecho fundamental de los padres sobre la educación moral y religiosa de sus hijos en el ámbito escolar. Por respeto a la libertad de conciencia, dicha enseñanza no tiene carácter obligatorio para los alumnos, pero sí se garantiza el derecho a recibirla. Por tanto, los planes educativos incluirán la enseñanza de la Religión Católica en todos los Centros de Educación, en condiciones equiparables a las demás disciplinas fundamentales. Además, nadie estará obligado a impartir enseñanza religiosa y los profesores de la misma formarán parte, a todos los efectos, del claustro de docentes de los respectivos centros. Esta enseñanza será impartida por las personas que, para cada año escolar, sean designadas por la autoridad académica entre aquéllas que proponga el Ordinario diocesano, quien, con antelación suficiente, comunicará los nombres de los profesores y personas que sean consideradas competentes para este cometido. Corresponde a la Jerarquía Eclesiástica señalar los contenidos de la enseñanza y formación religiosa católica,

49 Vid., entre otros muchos, M. López Alarcón, «Sistema matrimonial concordado. Celebración y efectos», C. Corral-L. Echeverría, Los acuerdos..., cit., pp. 291-331; J. B. Jordano Barea, «El nuevo sistema matrimonial español», en Anuario de Derecho Civil, 34 (1981), 903-926. Para un estudio interdisciplinar del Derecho matrimonial, Ma . M. Leal Adorna-Ma . R. León Benítez (coords.), La enseñanza interdisciplinar del Derecho matrimonial, Sevilla 2008.

50 Sobre este particular son incontables las publicaciones en el Derecho español. Para un análisis de la cuestión en la Unión Europea, véase, por ejemplo, Ma ${ }^{a}$ M. Leal Adorna-Ma . R. León Benítez, «El reconocimiento en los países de la Unión Europea de las sentencias de nulidad dictadas por los Tribunales Eclesiásticos», R. García García (coord.), El Derecho Eclesiástico a las puertas del siglo XXI, Madrid 2006, pp. 253-264.

51 Para el tema concreto de la enseñanza de la religión en el contexto educativo (la religión en la Ley Orgánica 2/2006, de 3 de mayo, de Educación, etc.), así como del régimen jurídico del profesorado de religión, vid., por ejemplo, Ma . R. León Benítez-Ma. M. Leal Adorna, Derecho..., cit., pp. 279-301. Asimismo, pueden consultarse, entre otros, A. Martínez Blanco, La enseñanza de la religión en los centros docentes (a la luz de la Constitución y del Acuerdo con la Santa Sede), Murcia 1994; J. M. Martí Sánchez, «Factor religioso y enseñanza en España», ADEE, XVI (2000), 399479; P. Lorenzo, Libertad religiosa y enseñanza en la Constitución, Madrid 2001; J. M. Martí Sánhez, «Enseñanza de la religión en la escuela en la última década», $A D E E$, XXI (2005), 495-534 y la bibliografía citada por este autor; Idem, «La "Educación para la Ciudadanía”. Ley Orgánica 2/2006, de Educación», ADEE, XXIII (2007), 211-256. 
así como proponer los libros de texto y material didáctico sobre la materia. Este Acuerdo también se ocupa, por ejemplo, del tema de los seminarios, universidades y otros centros de ciencias eclesiásticas para la formación de sacerdotes, religiosos y seglares. Asimismo, al margen de otras cuestiones, el Acuerdo precisa que la Iglesia reitera su voluntad de continuar poniendo al servicio de la sociedad su patrimonio histórico, artístico y documental. Para ello concertará con el Estado las bases para hacer efectivo el interés común y la colaboración de ambas partes a fin de preservar, dar a conocer y catalogar dicho patrimonio. A tal efecto, se crea una Comisión Mixta, formada por el Ministerio de Cultura con representación del de Exteriores y la Conferencia Episcopal Española ${ }^{52}$.

\section{Acuerdo sobre la Asistencia Religiosa a las Fuerzas Armadas y Servicio Militar de Clérigos y Religiosos (VIII arts.)}

Lo cierto es que tras la abolición del servicio militar obligatorio, el protagonismo en este tema lo adquiere la asistencia religiosa a los miembros católicos de las Fuerzas Armadas, que continuará ejerciéndose por medio del Vicariato Castrense ${ }^{53}$. Se trata de una Diócesis personal, no territorial, que consta de de un Arzobispo, Vicario General con su propia Curia, y, además, cuenta con la cooperación de los Vicarios Episcopales correspondientes y los Capellanes castrenses como párrocos personales. Dado que la jurisdicción del Vicario General Castrense y de los Capellanes es personal, la relación con los fieles no viene referida a un determinado territorio a través del domicilio o cuasidomicilio, sino que se extiende a una determinada categoría de personas, concretamente militares de Tierra, Mar y Aire, alumnos de las Academias y de las Escuelas Militares, sus esposas, hijos y familiares que viven en su compañía y, en general, todos aquellos que presten servicios de manera estable o residan habitualmente en este tipo de dependencias. Asimismo, los Capellanes Castrenses tienen competencia parroquial respecto a las personas mencionadas. En el supuesto de celebrarse el matrimonio ante los mismos, deberán atenerse a las prescripciones canónicas. No obstante, al ser la jurisdicción castrense cumulativa con la de los Ordinarios diocesanos, puede optarse por cualquiera de sendas jurisdicciones. Sin embargo, en todos los lugares e instalaciones dedicados a las Fuerzas Armadas u ocupados circunstancialmente por

52 A este respecto, J. M. González del Valle, Derecho Eclesiástico..., cit., p. 257. Asimismo, puede consultarse, por ejemplo, S. Meseguer Velasco, «La protección jurídica del patrimonio cultural de las confesiones religiosas», M. A. Jusdado Ruiz-Capillas (dir.), Derecho Eclesiástico del Estado, Madrid 2011, pp. 233-247.

53 Cfr. Disposición Adicional octava de la Ley 39/2007, de 19 de noviembre, de la carrera militar, que regula el servicio de asistencia religiosa y Real Decreto 1145/1990, de 7 de septiembre, por el que se crea el Servicio de Asistencia Religiosa a las Fuerzas Armadas y se dictan normas sobre su funcionamiento. En relación con este tema, véase, por ejemplo, A. Mostaza, «La asistencia religiosa a las Fuerzas Armadas y servicio militar de los clérigos», J. Giménez y Martínez de Carvajal-C. Corral, Iglesia y Estado en España, cit., pp. 245-266; J. M. Contreras Mazarío, La asistencia a los miembros de las Fuerzas Armadas en el ordenamiento jurídico español, Madrid 1988. 
ellas, usarán de la jurisdicción militar, primaria y principalmente, el Vicario General Castrense y los Capellanes. Cuando éstos falten o se encuentren ausentes, usarán de su jurisdicción subsidiariamente, aunque siempre por derecho propio, los Ordinarios diocesanos y los Párrocos locales.

\section{Acuerdo sobre Asuntos Económicos (VII arts.) ${ }^{54}$}

Se ocupa de las exenciones fiscales a favor de la Iglesia y del denominado «sistema de asignación tributaria». En este Acuerdo, la Iglesia manifiesta su propósito de lograr por sí misma los recursos suficientes para atender a sus necesidades. Adviértase, en relación con el mal llamado "impuesto religioso", que no se trata en realidad de un impuesto sino de una colaboración estatal a la Iglesia de un porcentaje del impuesto general sobre el rendimiento de las personas físicas que así lo manifiesten expresa y libremente, sin que ello suponga un "plus" de tributación en las arcas del Estado. En realidad, ni éste lo impone a sus súbditos por motivos religiosos ni la Iglesia lo impone a los suyos, cual es el caso de los países germánicos donde el Estado se encarga de su recaudación ${ }^{55}$. En Alemania no han faltado quienes hacen declaración de apostasía de su fe católica para así soslayar el pago del impuesto. Este problema no se da en España.

Últimamente ${ }^{56}$, como resultado de una serie de negociaciones iniciadas en el año 2005 entre el Gobierno español y la Conferencia Episcopal con el asenso de la Santa Sede, se ha instaurado un nuevo régimen jurídico en esta materia. Sus puntos básicos son los siguientes ${ }^{57}$ 1) sustitución del sistema de dotación

54 Entre los diversos trabajos sobre el tema, vid. Ma. Cebriá García, Autofinanciación de la Iglesia Católica en España. Limites y posibilidades, Salamanca 1999; el núm. 13 de la RGDCDEE (2007), iustel.com, última visita 8-9-2009, que dedica en su Sección Monográfica varios artículos al análisis de «La reforma del sistema de cooperación económica del Estado español con la Iglesia Católica»; J. Otaduy-D. Zalbidea (eds.), El sostenimiento económico de la Iglesia Católica en España. Nuevo modelo (Actas del Simposio sobre financiación de la Iglesia Católica), Pamplona 2008; F. Giménez Barriocanal, La financiación de la Iglesia Católica en España, Madrid 2007; Idem, «Financiación eclesial: situación actual y perspectivas de futuro», $I C$, 48 (2008), 25-68; A. C. Álvarez Cortina-M. Rodríguez Blanco (coords.), Aspectos del régimen económico y patrimonial de las confesiones religiosas, Edit. Comares, Granada 2008; S. Meseguer Velasco, «A propósito de la reforma del sistema de asignación tributaria: hacia el sostenimiento económico de las confesiones religiosas», RGDCDEE, 22 (2010), iustel.com, última visita 21-3-2012; R. Ma Ramírez Navalón (coord.), Régimen económico y patrimonial de las confesiones religiosas, Tirant lo Blanch, Valencia 2010.

55 A. Mostaza, «Sistema español de dotación estatal a la Iglesia», J. Giménez y Martínez de Carvajal-C. Corral, Iglesia y Estado en España, cit., pp. 178 y 188-190.

56 El 22 de septiembre de 2006, el Gobierno anunció públicamente el compromiso verbal alcanzado con la Iglesia Católica en materia económica, compromiso cuyo contenido fue confirmado por la Conferencia Episcopal. Sobre los pormenores del intercambio de Notas entre la Nunciatura y el Ministerio de Asuntos Exteriores, puede verse C. Corral, «El intercambio de Notas entre la Nunciatura en España y el Ministerio de Asuntos Exteriores y Cooperación (MAEC), de 22/12/2006, para fijar la asignación tributaria a la Iglesia», ADEE, XXIII (2007), 457-468.

57 Vid. Ley 42/2006, de 28 de diciembre, de Presupuestos Generales del Estado para el año 2007 y Orden EHA/39/2006, de 28 de diciembre. 
presupuestaria por el de asignación tributaria; 2) elevación del coeficiente actual de asignación tributaria del 0,52\% al 0,7\%;3) desaparición de las actuales exenciones y no sujeciones de la Iglesia Católica al IVA; 4) compromiso de ésta de presentar una memoria justificativa de las cantidades recibidas del Estado a través de la asignación tributaria.

Finalmente, tras este breve recorrido por el articulado de los Acuerdos con la Santa Sede, es preciso, a modo de síntesis, recordar que estos pactos ${ }^{58}: 1$ ) Constituyen una pluralidad de textos a diferencia del Concordato de 1953 que constituía un texto unitario y global. Por su parte, el Acuerdo de 1976 es programático, pues recoge unos principios generales que inspiraron la reforma. Lo relevante de este pacto, más que su contenido, es lo que realmente se dice en su Preámbulo: el compromiso de llegar, cuanto antes, a la conclusión de Acuerdos que sustituyan al Concordato a la sazón vigente. 2) Desde el punto de vista interno, dejan sentir los principios de no confesionalidad, libertad religiosa y cooperación. 3) Pueden calificarse de verdaderos tratados internacionales. Y ello porque la Santa Sede goza de personalidad internacional y, además, se siguió a la hora de su negociación y tramitación la práctica relativa a los tratados internacionales (se tramitaron por vía diplomática). 4) Han pasado a formar parte del Derecho interno español una vez publicados oficialmente en el BOE, el 15 de diciembre de 1979. Finalmente, no cabe dudar de su constitucionalidad, siendo doctrina unánime del Tribunal Constitucional y del Tribunal Supremo ${ }^{59}$.

\section{ACUERDOS CON OTRAS CONFESIONES RELIGIOSAS 60}

\section{A. Generalidades}

Desde la Edad Media la Santa Sede viene firmando concordatos con el poder temporal, en torno a los cuales gira el Derecho Eclesiástico de la confesión católica. Pero la posibilidad de suscribir acuerdos con otras confesiones es

58 Entre otros, A. Bernárdez, Lecciones..., cit., pp. 72-74; J. Fornés, El nuevo sistema..., cit., pp. 107-110; S. Bueno Salinas, «Los Acuerdos entre la Santa Sede y el Estado español a los 25 años de su vigencia», $R G D C D E E$, 8 (2005), iustel.com, última visita 7-9-2009.

59 STC 66/1982, de 12 de noviembre; SSTS de 12 de noviembre de 1980 y de 2 de diciembre de 1981 en relación con el Convenio de 5 de abril de 1962.

60 Vid., por ejemplo, A. C. Álvarez Cortina, «Los Acuerdos con las confesiones religiosas distintas a la Iglesia Católica en la doctrina española», ADEE, 8 (1992), 567-578; VV.AA., Acuerdos del Estado español con los judios, protestantes y musulmanes, Salamanca 1994; V. Reina- Ma A. Félix Ballesta (coords.), Acuerdos del Estado Español con Confesiones Religiosas Minoritarias (Actas del VII Congreso Internacional de Derecho Eclesiástico del Estado), Barcelona 1994; A. Fernández-Coronado, Estado y confesiones religiosas: un nuevo modelo de relación (Los pactos con las confesiones: Leyes 24, 25 y 26 de 1992), Madrid 1995; J. Mantecón Sancho, Los acuerdos del Estado con las confesiones acatólicas, Jaén 1995; Ma A. Félix Ballesta, «El régimen jurídico acordado en España sobre las peculiaridades culturales de las confesiones religiosas minoritarias», ADEE, XVI (2000), 85-222; J. Mantecón Sancho, Confesiones minoritarias en España. Guia de entidades y Vademécum normativo, Madrid 2004; C. Muñoz i Sala, Análisis comparativo entre los acuerdos Estado-confesiones religiosas de 1979 y de 1992 desde la perspectiva de los principios de la Constitución de 1978, Universidad Complutense de Madrid, 2004. 
una realidad que se llevó a cabo primero en Alemania, cuna del Derecho Eclesiástico, (Kichenverträge, de los Länder con las Iglesias evangélicas), después en Italia (Intese, con diversas confesiones acatólicas) y, desde hace dos décadas, en España ${ }^{61}$. Estos acuerdos con las minorías religiosas constituyen una novedad. Novedad que es factible a la luz del art. 7.1 de la LOLR: «El Estado, teniendo en cuenta las creencias religiosas existentes en la sociedad española, establecerá, en su caso, Acuerdos o Convenios de cooperación con las Iglesias, Confesiones y Comunidades religiosas inscritas en el Registro que por su ámbito y número de creyentes hayan alcanzado notorio arraigo ${ }^{62}$ en España. En todo caso, estos Acuerdos se aprobarán por ley de las Cortes Generales». El 10 de noviembre de 1992 se firmaron tres acuerdos con las confesiones judía e islámica (ambas no cristianas) y evangélica (cristiana). Concretamente, se firmaron con la Federación de Entidades Religiosas Evangélicas de España (FEREDE ${ }^{63}$ ), pacto que consta de doce artículos - y no sólo incluye confesiones protestantes, sino también la Iglesia Ortodoxa Griega en España, la Iglesia Ortodoxa Española ${ }^{64}$ y el Ejército de Salvación-, con la Federación de Comunidades Israelitas de España $\left(\mathrm{FCI}^{65}\right)$ y con la Comisión Islámica de España (CIE), ambos textos constan de catorce artículos $^{66}$. La Comisión Islámica está integrada, a su vez, por la Federación Española

61 J. M. González del Valle, Derecho Eclesiástico..., cit., pp. 81-86.

62 Vid., Ma J. Villa Robledo, «Reflexiones en torno al concepto de "notorio arraigo" en el artículo 7 de la Ley Orgánica de Libertad Religiosa», ADEE, I (1985), 143-184; J. Mantecón Sancho, Los acuerdos..., cit., pp. 17-21. La Comisión Asesora de Libertad Religiosa es el órgano competente para declarar cuándo una confesión ha adquirido notorio arraigo en España. Actualmente, lo tienen reconocido, además de las tres confesiones acatólicas que han suscrito acuerdos en 1992, la Iglesia de Jesucristo de los Santos de los Últimos Días (Mormones, 23-4-2003); los Testigos de Jehová (29-6-2006); la Federación de Comunidades Budistas de España (18-10-2007) y la Asamblea Episcopal Ortodoxa (15-4-2010).

63 Entre las diversas publicaciones sobre el tema, D. Basterra Monserrat, «Acuerdo Estado Español-Federación Evangélica», ADEE, VII (1991), 541-578; A. Fernández Coronado, «Los Acuerdos del Estado español con la Federación de Entidades Religiosas Evangélicas de España (F.E.R.E.D.E.) y la Federación de Comunidades Israelitas (F.C.I.). Consideraciones sobre los textos definitivos», ADEE, VII (1991), 541-578; R. García García-M. González Sánchez (coord.), Aplicación y desarrollo del Acuerdo entre el Estado español y la FEREDE, Madrid 2008.

${ }^{64}$ Para J. Mantecón Sancho (Los Acuerdos..., cit., p. 25) resulta muy llamativo que sendas Iglesias hayan solicitado su inscripción en la FEREDE y que ésta haya accedido a ello, dadas las acusadas diferencias de orden dogmático entre protestantes y ortodoxos. Así pues, quienes realmente firman un acuerdo de cooperación con el Estado español, no son ni unas Iglesias, ni unas Comunidades, ni unas Confesiones, tal como exige la letra de la LOLR, sino una Federación de Iglesias, caso de la FEREDE, o de Comunidades, supuestos de la FCI y de la CIE.

65 Vid., por ejemplo, A. Fernández-Coronado «Los Acuerdos del Estado español...», cit, pp. 541-578; I. Martín Sánchez-M. González Sánchez (coords.), Los judios en España. Cuestiones del Acuerdo de cooperación con la FCJE de 1992, Delta Publicaciones, Collado Villalba (Madrid), 2010.

66 Como se expondrá más adelante, la diferencia numérica en el articulado de los Acuerdos obedece a que los de la FCI y de la CIE tienen dos textos más sobre patrimonio histórico (art. 13) y sobre productos alimentarios y cosméticos (art. 14). Puede verse sobre este tema R. Ma . Ramírez Navalón, «Estudio comparativo del artículo 7 de los Acuerdos con la FEREDE, FCI y CIE», REDC, 54 (1997), 155-186. 
de Entidades Religiosas Islámicas (FEERI), sunníes y chíes, y por la Unión de Comunidades Islámicas de España (UCEIE), sólo sunníes ${ }^{67}$.

La LOLR no especifica el modo de concluir estos acuerdos, sólo precisa que “se aprobarán por Ley de las Cortes Generales". Proceden a su elaboración el Gobierno y la pertinente Confesión religiosa, aunque, como se ha escrito, en la práctica, estos acuerdos más que negociados parecen haber sido simplemente presentados a la firma de las Confesiones por parte del Gobierno, en la inteligencia de que "tres procesos negociadores diversos, con interlocutores distintos, lleguen a la conclusión de tres textos articulados prácticamente idénticos" 68 . Al no existir, pues, una regulación de conjunto sobre el tema, la doctrina entiende que el proceso se inicia con la propuesta de acuerdo realizada por la confesión pertinente al Ministerio de Justicia. Éste, a través de la Dirección General de Relaciones con las Confesiones, recogerá la información que considere oportuna de los distintos departamentos ministeriales, a los efectos de si fuera conveniente modificar la propuesta mediante nuevas conversaciones con la Confesión que pretende el pacto. Seguidamente, se somete a informe de la Comisión Asesora de Libertad Religiosa, a quien corresponde, con carácter preceptivo, pero no vinculante, la preparación y dictamen de este tipo de acuerdos de cooperación. Si no se pide el informe, queda viciado de nulidad el proceso, pero el Gobierno no está vinculado por él. Ese parece ser el momento para la firma del pacto entre la Confesión y el Gobierno, que inmediatamente lo aprobaría como proyecto de ley y lo remitiría al Parlamento, sometiéndose a debate y aprobación de las Cortes Generales. Al no exigirse expresamente ley orgánica, se trataría de una ley ordinaria, que deberá pasar por el Congreso y el Senado ${ }^{6}$. Estos Acuerdos firmados en España, que, dada su similitud, han sido calificados por algún autor, de acuerdos "clónicos" 70 , se han celebrado con Federaciones y Comisiones, en las que se integran distintas iglesias, comunidades o confesiones. Como ha precisado González del Valle, "La razón de que se haya procedido de este modo, parece responder a la necesidad de encontrar un interlocutor válido. Las confesiones religiosas no católicas presentes en España son muchas, cada una con una distinta jerarquía. En tales condiciones, hubiera sido necesario firmar un elevado número de acuerdos, pues cada suprema autoridad religiosa

67 Entre otros trabajos, L. Ruano Espina, «Derecho e Islam en España», IC, 43 (2003), 465 543; A. Motilla (ed.), Los musulmanes en España. Libertad religiosa e identidad cultural, Madrid 2004; Z. Combalía-Ma P. Diago Diago-A. González-Varas (coords.), Derecho islámico e interculturalidad, Iustel, Madrid 2011.

68 I. C. Ibán, «Normativa en el Derecho Eclesiástico del Estado», ponencia en el Workshop sobre Derecho Eclesiástico del Estado, Oñate 26-28 de mayo de 1993, p. 23 (pro manuscripto), citado por J. Mantecón Sancho, Los acuerdos..., cit., p. 30.

69 D. Llamazares, Derecho Eclesiástico del Estado, Madrid 1991, pp. 220-221; J. M. González del Valle, Derecho Eclesiástico..., cit., p. 96.

70 J. Bonet Navarro, «La celebración de festividades religiosas en los acuerdos de cooperación de 1992», REDC, 52 (1995), 305. 
sólo puede comprometerse en relación con su propia organización y afiliados. Por ello, desde la Comisión de Libertad Religiosa, se fomentó que se agrupasen por federaciones, de tal modo que el poder político pactase con la federación y no con cada una de las confesiones. Para ello, se les instó a agruparse en familias: protestante, judía e islámica" ${ }^{11}$. Al margen de otras consideraciones en torno a la fórmula del notorio arraigo del art. 7 de la LOLR, no cabe duda de que este requisito resulta más fácil de cumplir si la entidad del fenómeno que contemplan tiene la amplitud necesaria para que sea susceptible de ser regulado por ley. Por último y en lo que se refiere a la naturaleza jurídica de estos acuerdos con las minorías religiosas, ya se apuntó al principio de este trabajo que no tienen el rango de tratados internacionales sino de Derecho público interno, dado que uno de los sujetos carece de personalidad jurídica internacional, a diferencia de lo que ocurre con la Santa Sede ${ }^{72}$.

\section{B. Contenido de los acuerdos con las confesiones acatólicas}

Al margen de otros pormenores, los textos de la Exposición de Motivos de cada uno de los tres Acuerdos de 1992 que, por lo demás, coinciden prácticamente en su redacción, hacen hincapié en el hecho de que la Constitución de 1978, al configurar un Estado democrático y pluralista, ha supuesto un profundo cambio en la tradicional actitud de aquél ante el fenómeno religioso y consagra como fundamentales los derechos de igualdad y libertad religiosas, tanto en el ámbito individual como en el de las Confesiones o Comunidades en que los ciudadanos se integran para el cumplimiento comunitario de sus fines religiosos, sin necesidad de autorización previa ni de su inscripción en Registro público alguno. Asimismo, el Estado, también por imperativo constitucional, viene obligado al mantenimiento de relaciones de cooperación con las diferentes Confesiones, en la medida en que las creencias de la sociedad española lo demanden. A este fin, la Exposición de Motivos de cada uno de los Acuerdos insiste en los requisitos de notorio arraigo y de la inscripción en el Registro de Entidades Religiosas.

71 Derecho Eclesiástico..., cit., p. 93.

72 I. Martín Sánchez, «La naturaleza jurídica de los acuerdos mencionados en el artículo 7 de la Ley Orgánica de Libertad Religiosa y su posición en el sistema de fuentes del Derecho Eclesiástico del Estado», RGDCDEE, 7 (2005), iustel.com, última visita 8-9-2009. Se ha ocupado con rigor del tema de la naturaleza jurídica de los Acuerdos suscritos con las minorías religiosas, por ejemplo, L. Ruano Espina, «Los Acuerdos o Convenios de cooperación entre los distintos poderes públicos y las confesiones religiosas», REDC, 53 (1996),173-175. 
A continuación, se hará referencia a los temas más relevantes que se contemplan en el articulado de los tres Acuerdos ${ }^{73}$, temas que son coincidentes en los tres textos y en los que existe un paralelismo prácticamente tota $7^{74}$.

1. Los sujetos de los acuerdos (art. 1): dejando a un lado al Estado como elemento subjetivo susceptible de firmar acuerdos de cooperación, es preciso recordar, como se ha advertido anteriormente, que éstos no se firman por las Iglesias o Confesiones, sino por las correspondientes Federaciones. Por ello, el texto legal deja bien claro que los derechos y obligaciones derivados del respectivo acuerdo serán de aplicación a las Iglesias o Comunidades que, previamente inscritas en el Registro de Entidades Religiosas, formen parte o se incorporen posteriormente a la correspondiente Federación. Sin embargo, en el caso del acuerdo con la $\mathrm{Co}-$ misión Islámica, que, como se ha referido más arriba, representa a las dos Federaciones, FEERI y UCIE, lo habitual es que el sujeto último lo constituyan las Comunidades, siempre que estén inscritas y pertenezcan a una de estas dos $\mathrm{Fe}-$ deraciones. Es factible también que alguna Comunidad se encuentre vinculada directamente con la Comisión Islámica, sin necesidad de inscribirse en alguna de las Federaciones mencionadas ${ }^{75}$.

2. Lugares de culto, archivos y cementerios (art. 2): son lugares de culto los edificios o locales destinados de forma permanente y exclusiva a las funciones de culto, formación o asistencia religiosa, cuando así se certifique por la respectiva Iglesia o Comunidad, con la conformidad de la Federación. En los Acuerdos con judíos e islámicos se añade también, como elemento de identificación, la formación religiosa ${ }^{76}$. Por otra parte, estos lugares gozan de inviolabilidad. En lo que hace al tema de archivos, el único de los tres Acuerdos que alude a los mismos es el islámico, en el sentido de que son respetados y protegidos por el Estado. A propósito de los cementerios, sólo los textos judío e islámico regulan este tema, pudiendo disfrutar de los beneficios legales establecidos para los lugares de culto. Asimismo, se les reconoce el derecho a la concesión de parcelas para enterramiento en los cementerios municipales e, incluso, poseer cementerios privados o propios.

73 Para el análisis, siquiera sea sucinto, del contenido de los acuerdos con las confesiones acatólicas, se ha tenido muy presente el interesante trabajo de J. Mantecón Sancho, Los acuerdos..., cit., pp. 34-73. Asimismo, pueden consultarse, entre otros, D. García-Pardo, «El contenido de los acuerdos previstos en el artículo 7.1 de la Ley Orgánica de Libertad Religiosa», ADEE, XVI (2000), 223-308; Ma . A. Félix Ballesta, «El régimen jurídico acordado en España sobre las peculiaridades culturales de las confesiones religiosas minoritarias», $A D E E$, XVI (2000), 85-222.

74 Ibidem, p. 34.

75 Ibidem, p. 35.

76 Ibidem, p. 37. En relación con la FEREDE, puede consultarse Ma. M. Leal Adorna, «Aplicación y desarrollo del Acuerdo entre el Estado Español y la FEREDE: Los lugares de culto", Aplicación y desarrollo..., cit., pp. 281-302. Respecto de la CIE se ha ocupado del tema, entre otros, A. Motilla, «La protección de los lugares de culto islámicos», Los musulmanes en España..., cit., pp. 79-106. 
3. Ministros de culto (arts. 3-6): una serie de razones que no es el caso exponer en este trabajo han impedido que el concepto de ministro de culto acatólico, a diferencia del concepto de ministro católico (obispo, sacerdote, canónigo, etc.), tuviera una clara definición, de ahí que los Acuerdos de 1992 se hayan visto obligados a precisar qué debe entenderse por ministro evangélico, imán o rabino, es decir, qué personas gozan ante el Derecho español de este status. En apretada síntesis, se trataría de la dedicación personal al ministerio cultual-litúrgico y de formación religiosa o asistencia pastoral, así como de la estabilidad y permanencia en el cargo, exigencias que han de ser acreditadas por la respectiva Iglesia o Comunidad, con la conformidad del órgano competente de su Federación ${ }^{77}$. A semejanza de lo que sucede con los ministros católicos, los pertenecientes a estas tres Confesiones minoritarias no están obligados a declarar sobre hechos que les han sido revelados en el ejercicio de funciones de culto o de asistencia religiosa. El Acuerdo con los musulmanes ${ }^{78}$ precisa aún más y añade al texto la expresión "en los términos legalmente establecidos para el secreto profesional". Por otra parte, los Ministros de culto de las tres Confesiones, están incluidos en el Régimen General de la Seguridad Social, asimilados a trabajadores por cuenta ajena ${ }^{79}$. Finalmente, a efectos legales, las funciones de culto o asisten-

77 J. Mantecón Sancho, Los acuerdos..., cit., pp. 40-41. Precisa este autor que cuando el artículo tres del Acuerdo con la Comisión Islámica "define el perfil del ministro de culto musulmán, añade a las funciones específicas de tipo cultual y catequético-pastoral, comunes a las de los ministros evangélicos y judíos, las de dirección de su Comunidad. Esta adición, en el caso de los musulmanes parece responder a un aspecto importante propio del Islam. En efecto, lo político-social no es fácilmente escindible - ni siquiera conceptualmente - de lo específicamente religioso; de tal manera que la Comunidad de creyentes es una Comunidad político-religiosa, en la que sus dirigentes reúnen a la vez la doble condición de dirigentes religiosos y políticos de la Comunidad en cuanto tal. En este sentido, la dicción del artículo tres parece ser una concesión - si bien puramente formal - al concepto más tradicional de Comunidad musulmana. Sin embargo, para evitar que la dirección de la Comunidad pueda ser interpretada o actuada de manera abusiva, es decir, en clave no religiosa, sino política, el texto remacha el carácter exclusivamente religioso que han de tener estos dirigentes («son dirigentes religiosos islámicos e imames...»), y las propias Comunidades" [ibidem, pp. 41-42].

78 Vid., por ejemplo, D. García-Pardo, «Ministros de culto musulmanes», Los musulmanes en España..., cit., pp. 65-78.

$79 \mathrm{E}$ art. 5 del Acuerdo con la FCI, añade que esta asimilación tendrá lugar "en las mismas condiciones que la legislación vigente establece para los clérigos de la Iglesia Católica, con extensión de la protección a su familia”. Observa J. Mantecón Sancho (ibidem, p. 45) que aunque en los otros dos Acuerdos nada se dice al respecto, en aplicación del principio de igualdad, debe sobreentenderse. Esta extensión de la protección de la familia tiene su explicación por el hecho de que los Ministros de estas Confesiones, a diferencia de los católicos, pueden casarse.

E1 Real Decreto 2398/1977 constituye el texto fundamental sobre la seguridad social no sólo de los clérigos católicos sino también de los ministros de otras Confesiones inscritas en el Registro del Ministerio de Justicia. En relación con la inclusión en el régimen general de la Seguridad Social de los ministros de culto pertenecientes a la FEREDE, puede consultarse el Real Decreto 369/1999, de 5 de marzo; en el mismo sentido, el Real Decreto 822/2005, de 8 de julio a propósito de los clérigos de la Iglesia Ortodoxa Rusa del Patriarcado de Moscú en España y el Real Decreto 176/2006, de 10 de febrero acerca de los dirigentes religiosos e imames de las 
cia religiosa de los Ministros pertenecientes a la FEREDE son las dirigidas directamente al ejercicio del culto, administración de Sacramentos, cura de almas, predicación del Evangelio y magisterio religioso. Por su parte, el Acuerdo con la FCI considera funciones propias de la religión judía las que lo sean con arreglo a la Ley y a la tradición judía, como las de religión derivadas de la función rabínica, del ejercicio del culto, de la prestación de servicios rituales, de la formación de rabinos, de la enseñanza de la religión judía y de la asistencia religiosa. Y el Acuerdo con la CIE entiende por funciones islámicas de culto, formación y asistencia religiosa, las que lo sean según la Ley y la tradición islámica, emanadas del Corán o de la Sunna y protegidas por la LOLR.

4. Efectos civiles del matrimonio de las Confesiones acatólicas (art. 7) ${ }^{80}$ : el régimen jurídico viene a ser similar en los Acuerdos con evangélicos ${ }^{81}$ y judíos ${ }^{82}$, mientras que difiere en algunos puntos en el de los musulmanes. En primer lugar, el matrimonio de las tres Confesiones goza de efectos civiles y para el pleno reconocimiento de los mismos será necesaria la inscripción en el Registro Civil. No obstante, en el supuesto de matrimonios de judíos y musulmanes, se añade que estos efectos se reconocerán a los matrimonios celebrados «según la propia normativa formal israelita» o «según la forma religiosa establecida en la Ley Islámica», respectivamente. Por consiguiente, estaríamos ante matrimonios contraídos en forma religiosa con efectos civiles.

En el tema concreto de la celebración del matrimonio, los pactos con las minorías religiosas introducen algunas novedades en relación con el Acuerdo sobre Asuntos Jurídicos de la Confesión católica. Se trata del expediente civil previo al matrimonio y del certificado acreditativo de la capacidad matrimonial de los contrayentes. En efecto, las personas que deseen contraer matrimonio habrán de promover un expediente ante el encargado del Registro Civil. Una vez cumplido

comunidades integradas en la CIE. En general, sobre el tema de los ministros de culto incluidos en este régimen de la Seguridad Social, resulta de interés el trabajo de M. Rodríguez Blanco, «Relevancia de la condición de ministro de culto a efectos de la Seguridad Social», Relaciones Laborales, 6 (2002), 19-44.

80 Sobre el matrimonio religioso no católico, entre otros muchos, J. A. Jorge García Reyes, El matrimonio de las minorías religiosas en el Derecho español. Evolución histórica y regulación en la Ley de 7 de julio de 1981, Madrid 1986; R. Rodríguez Chacón, «El matrimonio religioso no católico en Derecho español», ADEE, 10 (1994), 369-428; I. García Rodríguez, La celebración del matrimonio religioso no católico, Madrid 1999; $\mathrm{M}^{\mathrm{a}}$. A. Félix Ballesta, «El régimen jurídico...», cit., pp. 147-185; M. López Alarcón-R. Navarro-Valls, «El régimen matrimonial de las confesiones acatólicas», Curso de Derecho matrimonial canónico y concordado, Madrid 2001, pp. 491-495.

81 Puede verse, entre otros trabajos, $\mathrm{M}^{\mathrm{a}}$. L. Labaca Zabala, «El matrimonio celebrado en forma religiosa evangélica y su trascendencia en el ordenamiento jurídico español», Aplicación y desarrollo..., cit., pp. 139-168; C. Pons-Estel Tugores, «E1 matrimonio celebrado en forma religiosa anglicana en España», ibidem, pp. 169-188.

82 Un estudio amplio sobre el Derecho matrimonial en el judaísmo lo realiza M. Perales Agustí, «La mujer en el Derecho y el matrimonio judío», I. Ma Briones Martínez (coord.): Mujer y factor religioso, RGDCDEE, 20 (2009), iustel.com, última visita 25-9-2009. 
este trámite, el Juez Encargado de dicho Registro expedirá, por duplicado, certificación acreditativa de la capacidad matrimonial, que los contrayentes deberán entregar al ministro de culto encargado de la celebración. Para la validez civil de esta unión, el consentimiento habrá de prestarse ante el ministro de culto oficiante $^{83}$ de la ceremonia y, al menos, dos testigos mayores de edad, siempre que no hayan transcurrido más de seis meses desde la expedición de la certificación de capacidad matrimonial. Sin embargo, el Acuerdo con la CIE difiere de este sistema ${ }^{84}$, al no exigir imperativamente expediente previo y consiguiente certificación acreditativa de la capacidad matrimonial, pues sólo establece que "se atribuye efectos civiles al matrimonio celebrado según la forma religiosa establecida en la Ley Islámica, desde el momento de su celebración, si los contrayentes reúnen los requisitos de capacidad exigidos por el Código Civil”. A diferencia de los Acuerdos con judíos y evangélicos, la acreditación de esta capacidad no es necesario que se realice a través de expediente previo a la celebración del matrimonio, sino mediante simple certificación expedida por el Registro Civil antes de la inscripción. A tal fin, una Instrucción de $1993^{85}$ precisa que tratándose de matrimonios celebrados en la forma religiosa islámica, si excepcionalmente los interesados prescinden bajo su responsabilidad del trámite previo de expedición del certificado de capacidad matrimonial, la calificación que se lleve a cabo antes de la inscripción, habrá de abarcar no sólo los requisitos formales de esta certificación, sino también todos los requisitos de fondo exigidos para la validez del matrimonio. Pero, como regla general, quienes pretendan contraer matrimonio islámico pueden acudir también al expediente previo más certificación acreditativa de capacidad matrimonial, lo que resulta aconsejable a los efectos de facilitar la posterior inscripción ${ }^{86}$. En síntesis, el matrimonio de evangélicos y judíos habrá de celebrarse antes de que hayan transcurrido seis meses desde la expedición de la certificación de capacidad matrimonial. Sin embargo, en el

83 No se exige la nacionalidad española de los ministros, pero necesariamente han de pertenecer a la FEREDE, a la FCI o a la CIE (vid., por ejemplo, R. Navarro-Valls, «El matrimonio religioso", Derecho Eclesiástico..., cit., p. 374).

84 Ibidem, pp. 373-374. Para el matrimonio islámico en particular pueden consultase, entre otros, J. Bonet Navarro, «El matrimonio en el Derecho islámico», Curso de Derecho matrimonial y procesal canónico para profesionales del Foro, 11 (Salamanca 1994), pp. 467-481; Z. Combalía, «Mujer y matrimonio en el Derecho islámico», Conciencia y Libertad, 13 (2001), 35-56; A. Motilla-P. Lorenzo, Derecho de familia islámico. Los problemas de adaptación al Derecho español (obra coordinada por Ma. J. Ciáurriz), Madrid 2002; S. Acuña-R. Domínguez Bartolomé, «Aproximación al matrimonio musulmán en la Sharia», IC, 84 (2002), 571-614; A. Motilla (coord.), El matrimonio islámico y su eficacia en el Derecho español, Córdoba 2003; Ma. E. Olmos, «Mujer, Matrimonio e Islam», ADEE, XXIV (2008), 493-524; A. Fernández-Coronado, «Matrimonio islámico, orden público y función promocional de los derechos fundamentales», Revista Española de Derecho Constitucional, 85 (2009), 125-156.

85 Instrucción de 10 de febrero de 1993, de la Dirección General de los Registros y del Notariado, sobre la inscripción en el Registro Civil de determinados matrimonios celebrados en forma religiosa.

86 R. Navarro-Valls, «El matrimonio...», J. Ferrer Ortiz (coord.), Derecho Eclesiástico..., cit., p. 374. 
caso de los musulmanes, dicho matrimonio se podría celebrar pero no inscribir en el Registro ${ }^{87}$.

En el tema concreto de la inscripción registral del matrimonio acatólico, se establecen, al igual que en el caso del matrimonio canónico, dos procedimientos: el realizado por los propios contrayentes y el efectuado por el ministro de culto. Sin embargo, el primer procedimiento no se establece como principal sino como subsidiario. En los Acuerdos se hace una alusión indirecta al mismo cuando se dice que la inscripción podrá ser promovida «en cualquier tiempo» mediante presentación de la certificación convenientemente diligenciada. De este modo, el procedimiento ordinario será el realizado por el ministro oficiante. También en relación con la inscripción registral de estas uniones, hay que mencionar otra diferencia con el procedimiento que regula el Acuerdo sobre Asuntos Jurídicos entre la Santa Sede y el Estado Español. En este texto se establece un plazo de cinco días para que el párroco transmita al encargado del Registro Civil el Acta del matrimonio canónico para su oportuna inscripción, siempre que ésta no se haya efectuado ya a instancia de las partes interesadas. Por el contrario, los Acuerdos con la FEREDE y con la FCI establecen que se remitirá «acto seguido» al encargado del Registro Civil competente para su inscripción. La ambigüedad de esta expresión, puede generar incertidumbre o una innecesaria inquietud, pues, en defecto de inscripción «acto seguido» por el ministro oficiante, podrá ser promovida «en cualquier tiempo», también por los propios contrayentes ${ }^{88}$.

Por último, a diferencia de lo que sucede con las resoluciones eclesiásticas de nulidad o disolución del matrimonio no consumado, los Acuerdos de 1992 no atribuyen eficacia civil a las sentencias de nulidad, separación y divorcio de los matrimonios de evangélicos, judíos y musulmanes. Será, por tanto, de aplicación la normativa civil española.

5. Asistencia religiosa: los Acuerdos distinguen entre la asistencia a los militares y la prestada a los internados en centros o establecimientos públicos penitenciarios, hospitalarios y asistenciales.

- En las Fuerzas Armadas (art. 8): se reconoce el derecho de todos los militares evangélicos, judíos y musulmanes, sean o no profesionales, y de las personas pertenecientes a estas religiones que presten servicio en las Fuerzas Armadas, a participar en las actividades y ritos propios de aquéllas, previa la oportuna autorización de sus Jefes, quienes procurarán que dichas prácticas religiosas sean compatibles con las necesidades del servicio, facilitando los lugares y medios adecuados para su desarrollo. Los Acuerdos con judíos y musulmanes contemplan la posibilidad de que, a falta de Sinagoga o Mezquita u oratorio en el lugar de destino, pueda autorizarse el cumplimiento de dichas prácticas en la

87 J. Mantecón Sancho, Los acuerdos..., cit., p. 51.

88 R. Navarro-Valls, «El matrimonio...»,J.Ferrer Ortiz (coord.), Derecho Eclesiástico, cit.,pp.374-375. 
localidad más próxima cuando las necesidades del servicio lo permitan. Por otra parte, la asistencia religiosa será dispensada por los ministros de culto designados, respectivamente, por las Iglesias pertenecientes a la FEREDE con la conformidad de ésta, por las Comunidades integrantes de la FCI y por las $\mathrm{Co}_{-}$ munidades Islámicas pertenecientes a la CIE. Además, en este último caso, la asistencia religiosa habrá de ser dispensada por una persona nombrada «con carácter estable». Asimismo, se requiere la autorización por parte de los Mandos del Ejército, quienes colaborarán para que puedan desempeñar sus funciones en iguales condiciones que los ministros de culto de otras Confesiones que tengan concertados acuerdos de cooperación con el Estado, como es el caso de la Iglesia Católica.

- En centros penitenciarios, hospitalarios y asistenciales públicos (art. 9): se garantiza el ejercicio de este derecho a la asistencia religiosa por medio de los respectivos ministros de culto designados al efecto y debidamente autorizados por los centros o establecimientos públicos correspondientes. Los Acuerdos con los judíos y musulmanes son más explícitos que el propio con la FEREDE, al exigir a las direcciones y establecimientos públicos que transmitan a sendas Comunidades las solicitudes de asistencia espiritual recibidas de los internos o de sus familiares, si los propios interesados no estuvieran en condiciones de hacerlo. Por lo demás, en los tres Acuerdos se establece que el acceso de los ministros a dichos centros será libre y sin limitación de horario. Asimismo, la asistencia religiosa se prestará con el debido respeto al principio de libertad religiosa y con la debida observancia de las normas de organización y régimen interno de los centros. En el tema concreto de los establecimientos penitenciarios, dicha asistencia se realizará de acuerdo con lo dispuesto en la legislación penitenciaria ${ }^{89}$. Por otra parte, la prevista para judíos e islámicos también comprende la que se dispensa a los moribundos, así como las honras fúnebres del propio rito. Finalmente, sin perjuicio de la utilización de los locales que, a tal fin, existan en los diferentes centros, los gastos que origine el desarrollo de esta asistencia espiritual correrán a cargo de las Iglesias o Comunidades respectivas en el caso de evangélicos y judíos, mientras que en el Acuerdo con los musulmanes se establece que dichos gastos serán sufragados en la forma que pacten los representantes de la «Comisión Islámica de España» con la dirección de los centros y establecimientos públicos pertinentes.

89 Vid. Real Decreto 710/2006, de 9 de junio, de desarrollo de los Acuerdos de cooperación firmados por el Estado con la Federación de Entidades Religiosas Evangélicas de España, la Federación de Comunidades Judías de España y la Comisión Islámica de España, en el ámbito de la asistencia religiosa penitenciaria. Sobre asistencia religiosa islámica, puede verse $\mathrm{M}^{\mathrm{a}}$.J. Ciáurriz, «La asistencia religiosa islámica en los centros públicos», Los musulmanes en España..., cit., pp. 137-166. 
6. Educación y enseñanza religiosa (art. 10) ${ }^{90}$ : en los tres Acuerdos se garantiza a los alumnos, a sus padres y a los órganos escolares de gobierno que lo soliciten, el ejercicio del derecho de los primeros a recibir enseñanza religiosa evangélica ${ }^{91}$, judía o islámica ${ }^{92}$, en los centros docentes públicos y privados concertados, siempre que, en cuanto a estos últimos, el ejercicio de aquel derecho no entre en conflicto con el carácter propio del centro, en los niveles de educación infantil, primaria y secundaria. Los profesores y los contenidos de la mencionada enseñanza, así como los libros de texto, serán designados y señalados —o proporcionados (caso de los musulmanes) - por las respectivas Iglesias o Comunidades, con la conformidad de la Federación o Comisión correspondiente. Sin embargo, serán los centros los obligados a facilitar los locales adecuados para el ejercicio de este derecho, siempre que no perjudique el desenvolvimiento de las actividades lectivas. No falta en los tres Acuerdos la posibilidad de organizar cursos de enseñanza religiosa en los centros universitarios públicos, pudiendo utilizar los locales y medios de los mismos. Para ello se requiere acuerdo previo con las autoridades académicas, salvo en el caso de la «Comisión Islámica de España»o de sus Comunidades miembros, que pueden organizar estas actividades directamente. Por último, también es factible establecer y dirigir centros docentes de los diferentes niveles educativos, así como centros universitarios, seminarios de carácter religioso y otras Instituciones de Estudios Eclesiásticos o Centros de Formación Islámica, con sometimiento a la legislación general vigente en la materia.

90 Entre otros, S. Tarrés-F. J. Rosón, «La enseñanza de las religiones minoritarias en la escuela: análisis del caso de Andalucía», Revista de Ciencias de las Religiones, 14 (2009), pp. 179-197.

91 Vid., por ejemplo, B. González Moreno, «La enseñanza religiosa evangélica: Aplicación y desarrollo del Acuerdo entre el Estado español y la FEREDE», Aplicación y desarrollo..., cit., pp. 303-344; G. Moreno Botella (dir.), La enseñanza religiosa evangélica en la Comunidad Autónoma de Madrid, Edit. Colex, Madrid 2009.

92 Sin ánimo de exhaustividad, pueden consultarse P. Lorenzo-Ma. T. Peña, «La enseñanza religiosa islámica», Los musulmanes en España..., cit., pp. 249-280; Ma . J. Ciáurriz-D. García PardoP. Lorenzo-A. Motilla-J.Rossell, La enseñanza islámica en la Comunidad de Madrid, Madrid 2004; A. Motilla (ed.), Islam y derechos humanos, Madrid 2006; Ma . Cebriá García, «La enseñanza de la religión islámica en los centros docentes españoles», RGDCDEE, 18 (2008), iustel.com, última visita 8-9-2009; A. Rodríguez Moya, «Libertad religiosa y enseñanza de la religión: especial atención al caso islámico», RGDCDEE, 20 (2009), iustel.com, última visita 8-9-2009. Como dato curioso, en la actualidad, Ceuta es la única ciudad que cuenta con un colegio en el que sólo se imparte enseñanza religiosa islámica. Para una mayor información sobre el tema puede verse $M^{\text {a }}$. $M$. Leal Adorna, «La regulación del factor religioso en las Ciudades Autónomas de Ceuta y Melilla», La libertad religiosa..., cit., p. 658.

Lógicamente, no se hace alusión al polémico tema del pañuelo islámico en la escuela, pues excede de los propios límites del presente trabajo. Sobre el uso del velo islámico hay una interesante bibliografía de la que, a modo de ejemplo, puede verse A. Motilla, «La libertad de vestimenta: el velo islámico», Los musulmanes en España..., cit., pp. 107-136. Para un estudio de esta cuestión en Europa, con un buen número de indicaciones legislativas y jurisprudenciales, véase Idem (coord.), El pañuelo islámico en Europa, Madrid 2009. 
7. Asuntos económicos y fiscales (art. 11): en términos prácticamente idénticos al Acuerdo sobre Asuntos Económicos de la Iglesia Católica con el Estado español, se reconoce a las diferentes Iglesias y Comunidades la facultad de recabar libremente de sus fieles prestaciones, organizar colectas públicas y recibir ofrendas y liberalidades de uso. El régimen de cooperación económica de estas minorías difiere del propio de la Confesión católica, pues sólo se da una cooperación de tipo indirecto que se concreta en un sistema de exenciones tributarias y beneficios fiscales. Asimismo, las diferentes Iglesias y Comunidades tendrán derecho a los demás beneficios fiscales que el ordenamiento jurídico-tributario del Estado español prevea en cada momento para las entidades sin fin de lucro y, en todo caso, a los que se concedan a las entidades benéficas privadas. Iguales beneficios se contemplan para las asociaciones y entidades creadas y gestionadas por las referidas Confesiones, siempre que se dediquen a actividades religiosas, benéfico-docentes, médicas y hospitalarias o de asistencia social. Finalmente, a través de la normativa del Impuesto sobre la Renta de las Personas Físicas se regulará el tratamiento tributario aplicable a los donativos que se realicen a las mencionadas Iglesias y Comunidades, con las deducciones que, en su caso, pudieran establecerse ${ }^{93}$.

8. Descanso semanal y otras festividades (art. 12): dejando a un lado la mayor dificultad o conflictividad que encierra este tema, dado que para los musulmanes el día festivo semanal de carácter religioso es el viernes y para los judíos y algunas Iglesias evangélicas, el sábado, se ha pactado que el descanso laboral semanal para los fieles de estas dos últimas confesiones podrá comprender, siempre que medie acuerdo entre las partes, la tarde del viernes y el día completo del sábado, en sustitución del que establece el Estatuto de los Trabajadores como regla general. Sin embargo, el caso de los musulmanes ${ }^{94}$ resulta más singular en la medida en que los miembros de las Comunidades pertenecientes a la «Comisión Islámica de España» podrán solicitar la interrupción de su trabajo los viernes de cada semana, día de rezo colectivo obligatorio y solemne, desde las trece treinta hasta las dieciséis treinta horas, así como la conclusión de la jornada laboral una hora antes de la puesta del sol, durante el mes de ayuno (Ramadán). En ambos casos, se requiere el acuerdo previo entre las partes y las horas no trabajadas deberán ser recuperadas sin compensación alguna.

Por lo que se refiere a otras festividades o conmemoraciones, llama la atención que el Acuerdo con la FEREDE no haga mención alguna de estas solemnidades. La razón habría que encontrarla en el hecho de que, salvo alguna fiesta como, por ejemplo, la de la Inmaculada Concepción, San José o Corpus Christi,

93 J. Mantecón Sancho, Los acuerdos..., cit., pp. 60-65. Vid. también, por ejemplo, J. M. Contreras Mazarío, «La financiación “directa” de las minorías religiosas en España. Especial referencia a las Comunidades Evangélicas», Aplicación y desarrollo..., cit., pp. 211-252.

94 Vid., por todos, D. García-Pardo, «Descanso semanal y festividades religiosas islámicas», Los musulmanes en España..., cit., pp. 167-204. 
las demás festividades cristianas, en especial Navidad y Semana Santa, son compartidas por la mayoría de las Iglesias que forman parte de aquella Federación ${ }^{95}$. Por el contrario, los Acuerdos con judíos y musulmanes sí recogen sus propias festividades religiosas anuales, que podrán sustituir, siempre que medie acuerdo entre las partes, a las establecidas con carácter general por el Estatuto de los Trabajadores, con el mismo carácter de retribuidas y no recuperables, a petición de los fieles pertenecientes a las Comunidades israelita o islámica.

Los Acuerdos también hacen referencia a la posible dispensa de asistencia a clase y de la celebración de exámenes ${ }^{96}$ a los alumnos que cursan estudios en centros de enseñanza públicos o privados concertados, a petición propia o de sus padres o tutores. Por último, los exámenes, oposiciones o pruebas selectivas convocadas para el ingreso en las Administraciones Públicas, que hayan de celebrarse dentro de los períodos de tiempo anteriormente indicados, serán convocados en una fecha alternativa cuando no haya causa motivada que lo impida.

9. Patrimonio histórico-artístico (art. 13): el Acuerdo con la FEREDE no regula esta materia, acaso por la falta de este patrimonio de origen protestante en España debido a su tardía presencia en nuestro país ${ }^{97}$. Los Acuerdos con la FCI y la CIE se muestran en la línea positiva de colaborar en la conservación y fomento del patrimonio histórico, artístico y cultural judío e islámico, que continuará al servicio de la sociedad para su contemplación y estudio. Esta colaboración se extiende a la confección de un catálogo e inventario de dicho patrimonio. Incluso, no falta la creación de Patronatos, Fundaciones u otro tipo de

95 J. Mantecón Sancho, Los acuerdos..., cit., pp. 65-68.

96 Los días y horas vienen indicados en los Acuerdos. Concretamente, los alumnos pertenecientes a la Unión de Iglesias Adventistas del Séptimo Día y de otras Iglesias evangélicas pertenecientes a la Federación de Entidades Religiosas Evangélicas de España, estarán dispensados desde la puesta del sol del viernes hasta la puesta del sol del sábado. Por su parte, los alumnos judíos lo estarán en el día de sábado y en las festividades siguientes: Año Nuevo (Rosh Hashaná), 1. ${ }^{\circ}$ y $2 .^{\circ}$ día; Día de Expiación (Yon Kippur); Fiesta de las Cabañas (Succoth), $1 .^{\circ}, 2 .^{\circ}, 7^{\circ}$ y $8 .^{\circ}$ día; Pascua (Pesaj), $1 .^{\circ}, 2 .^{\circ}, 7 .^{\circ}$ y $8 .^{\circ}$ día; Pentecostés (Shavuot), $1 .^{\circ}$ y $2 .^{\circ}$ día. Finalmente, los alumnos musulmanes estarán dispensados en el día del viernes, desde las trece treinta hasta las dieciséis treinta horas, y en las festividades y conmemoraciones siguientes: Al-Hichra (Hégira), correspondiente al 1. ${ }^{\circ}$ de Muharram, primer día del Año Nuevo Islámico, recuerda la emigración del Profeta $\mathrm{Mu}-$ hammad y sus seguidores de La Meca a Medina en el año 622; Achurá, décimo día de Muharram, conmemora la muerte de Husayn, nieto del Profeta Muhammad, en la población de Kerbalá (Irak); Idu-1-Maulid, que corresponde al 12 de Rabiu-1-Awwal, nacimiento del Profeta; Al-Israa wa-1-Mi'rach, que corresponde al 27 de Rayab, fecha del Viaje Nocturno y la Ascensión del Profeta; Idu-1-Fitr, correspondiente a los días $1 .^{\circ}, 2 .^{\circ}$ y $3 .^{\circ}$ de Shawwal y que celebra la culminación del Ayuno de Ramadán; Idu-1-Adha, que corresponde a los días $10 .^{\circ}, 11 .^{\circ}$ y $12 .^{\circ}$ de Du-1-Hiyya y que celebra el sacrificio protagonizado por el Profeta Abraham. Véase para el ámbito islámico G. Vercellin, Instituciones del mundo musulmán, trad., J. R. Monreal, Barcelona 2003, pp. 232-233; P. Cano Ávila, «Prácticas islámicas piadosas, reprobadas y otros hechos escatológicos», IV Estudios de Frontera. Historia, tradiciones y leyendas en la frontera. Homenaje a don Enrique Toral y Peñaranda, F. Toro y J. Rodríguez (coord.), Jaén 2002, pp. 91-108 y, especialmente, 99-101.

97 J. Mantecón Sancho, Los acuerdos..., cit., p. 70. 
instituciones de carácter cultural. Sin embargo, aunque existe gran similitud con el régimen establecido en el Acuerdo con la Iglesia Católica de 1979, en estos últimos textos no se hace referencia a la constitución de una Comisión Mixta entre el Estado y los representantes de sendas confesiones, lo que ha llevado a considerar que se está haciendo una mera declaración de intenciones ${ }^{98}$.

10. Marcas y productos judios e islámicos (art. 14): al igual que acontece con lo referido en el apartado anterior, esta materia no la regula el Acuerdo con la FEREDE. Se trata de una temática que tiene que ver con el sacrificio ritual de animales y con la elaboración de alimentos o cosméticos. Concretamente, por lo que hace a la tradición judía, las denominaciones «Casher» y sus variantes, «Kasher», «Kosher», «Kashrut» y éstas asociadas a los términos «U», «K» o «Parve», son las que sirven para distinguir los productos alimentarios y cosméticos elaborados de acuerdo con la Ley judía. Igualmente, el término «Halal»99 sirve para distinguir los productos alimentarios que lo sean según las peculiaridades de la Ley islámica. En ambos casos, hay que solicitar y obtener del Registro de la Propiedad Industrial los registros de las marcas correspondientes. De este modo, los productos que lleven en sus envases el correspondiente distintivo se consideran comercializados con la garantía de haber sido elaborados de conformidad con la Ley y la tradición judía o la Ley islámica. Asimismo, el sacrificio de animales realizado de acuerdo con las leyes propias de estas Comunidades, habrá de respetar la normativa sanitaria vigente. Todavía, el Acuerdo con la Comisión Islámica abunda más en este tema, en el sentido de que la alimentación de los internados en centros o establecimientos públicos y dependencias militares, y la de los alumnos musulmanes de los centros docentes públicos y privados que lo soliciten, se procurará adecuar a los preceptos religiosos islámicos, así como el horario de comidas durante el Ramadán.

A modo de epílogo y sin intención de hacer crítica alguna, pues este modesto trabajo sólo pretende realizar un recorrido descriptivo de los diferentes pactos del Estado con las Confesiones religiosas, no cabe duda de que la firma de estos Acuerdos con las minorías acatólicas constituye una auténtica novedad en el ámbito propio de las fuentes del Derecho Eclesiástico español. Se ha intentado crear un instrumento jurídico sencillo, aunque lo suficientemente completo para ser capaz de desarrollar paralelamente las mismas materias que han sido objeto de acuerdos con la Iglesia Católica, poniéndose así sobre el tapete cierta

98 Por ejemplo, J. Martínez-Torrón, Separatismo y cooperación en los acuerdos del Estado con las minorías religiosas, Granada 1999, p. 161, citado por S. Meseguer Velasco, «La protección jurídica del patrimonio cultural...», cit., p. 242.

99 Se han ocupado del tema, entre otros, J. Rossell, «Prescripciones alimentarias en el Islam: sacrificio ritual y alimentación Halal», Los musulmanes en España..., cit., pp. 205-228; I. JiménezAybar, «La alimentación "Halãl” de los musulmanes en España: aspectos jurídicos, económicos y sociales», IC, 90 (2005), 631-666; M. Vidal Gallardo, «Prescripciones alimentarias y nueva ley de libertad religiosa y de conciencia. Particular referencia a la Comunidad Islámica», $A D E E, \mathrm{XX}-$ VII (2011), 177-208. 
voluntad de aplicar el principio de igualdad. En términos generales, se han reunido en un solo texto los temas o materias que han sido acordados con la Confesión católica en cuatro Acuerdos, si se excluyen, lógicamente, los de 1962 y 1976. El hecho de que el número de artículos de que constan los Acuerdos de 1992 sea considerablemente inferior y, al mismo tiempo, regule las mismas materias que los Acuerdos con la Iglesia Católica de 1979, encuentra su explicación en la menor complejidad organizativa e implantación social de las Confesiones acatólicas. Ciertamente, hay lagunas en estos Acuerdos, pero la equiparación con lo pactado con la Iglesia Católica resulta realmente satisfactoria en muchos aspectos, si bien no lo es tanto en otros. En síntesis, independientemente de que estos pactos constituyen una realidad positiva, cabe pensar que a la Administración le ha faltado cierta generosidad en la medida en que sólo ha pretendido dar una especie de satisfacción moral, con más efectos psicológicos que jurídicos, a unas Confesiones realmente discriminadas en el pasado. Por su parte, éstas han adolecido de la suficiente audacia en sus planteamientos, ya que el resultado final es una normativa que poco innova sobre la ya existente ${ }^{100}$.

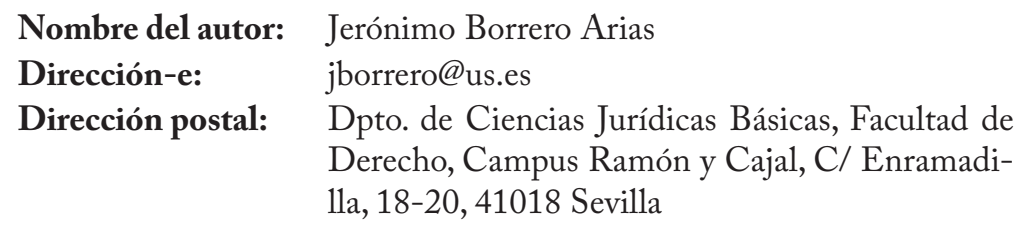

Fecha de recepción: 23/03/2012

Fechade aceptación: 09/07/2012

100 Vid., por todos, J. Mantecón Sancho, Los acuerdos..., cit., pp. 75-81. Sobre la necesidad o no de los Acuerdos con las minorías religiosas puede verse el interesante artículo de A. de la Hera, «Acuerdos con las confesiones religiosas minoritarias», IC, 69 (1995), 201-232. 
